NBER WORKING PAPER SERIES

\title{
IMPLICIT CONTRACTS, THE GREAT DEPRESSION, AND INSTITUTIONAL CHANGE: A COMPARATIVE ANALYSIS OF U.S. AND JAPANESE EMPLOYMENT RELATIONS, 1920-1940
}

\author{
Chiaki Moriguchi \\ Working Paper 9559 \\ http://www.nber.org/papers/w9559
NATIONAL BUREAU OF ECONOMIC RESEARCH 1050 Massachusetts Avenue
Cambridge, MA 02138
March 2003

This paper is partly based on my doctoral dissertation. I am deeply indebted to my thesis advisors, Avner Greif, Gavin Wright, Masahiko Aoki, and John Pencavel. I am grateful to Lee Alston, Carliss Baldwin, Samuel Bowles, Adam Brandenburger, Amit Bubna, Louis Cain, David Fairris, Joe Ferrie, Price Fishback, Robert Gibbons, Claudia Goldin, Rakesh Kurana, Robert Margo, Jim Minifie, Joel Mokyr, Laura Owen, Ben Polak, Daniel Raff, Paul Rhode, William Tsutsui, and Warren Whatley for their valuable comments. I would also like to thank seminar participants at Northwestern University, MIT, Harvard University, Santa Fe Institute, Stanford University, Stockholm School of Economics, UC Irvine, UCLA, University of Michigan, University of Pennsylvania, and University of Southern California for their helpful discussions. All remaining errors are mine. The views expressed herein are those of the authors and not necessarily those of the National Bureau of Economic Research.

(C2003 by Chiaki Moriguchi. All rights reserved. Short sections of text not to exceed two paragraphs, may be quoted without explicit permission provided that full credit including Cnotice, is given to the source. 
Implicit Contracts, the Great Depression, and Institutional Change:

A Comparative Analysis of U.S. and Japanese Employment Relations, 1920-1940

Chiaki Moriguchi

NBER Working Paper No. 9559

March 2003

JEL No. N30, N40, N60

\begin{abstract}
This paper employs a game-theoretic framework and a comparative historical analysis to study the impact of the Great Depression on "corporate welfarism," i.e., employers' voluntary provisions of non-wage benefits, greater employment security, and employee representation to their blue-collar workers. By characterizing corporate welfarism as an implicit contract equilibrium, the paper documents parallel institutional developments in the U.S. and Japan towards corporate welfarism during the 1920s and identifies the early 1930s as a bifurcation point at which the two trajectories began to diverge toward two distinctive equilibria. In the U.S., the repudiation of the implicit contracts by most leading firms induced by a deep depression caused a change in the expectations of workers and the public, which, in turn, supported a legal reform and the adoption of explicit employment contracts based on industrial unions and third-party enforcement. Experiencing a less severe depression, most major employers in Japan maintained their implicit contracts, while developing institutional arrangements to mitigate the cost of long-term commitment. In contrast to the U.S., labor laws in Japan developed complementary to private welfare practices, endorsing corporate welfarism based on implicit contracts and internal enforcement mechanisms.
\end{abstract}

\author{
Chiaki Moriguchi \\ Department of Economics \\ Northwestern University \\ 2001 Sheridan Road \\ Evanston, IL 60208 \\ and NBER \\ chiaki@northwestern.edu
}




\section{Introduction}

The rise of private welfare capitalism - employers' voluntary provision of non-wage benefits, greater employment security, and employee representation to their blue-collar workers - in the U.S. during the 1920s and its downfall in the 1930s have been a central subject of a number of historical studies. ${ }^{1}$ Yet, there is a continuing debate over its importance and implications for the subsequent development of American industrial relations. Some historians have argued that the primary motive of private welfare capitalism was to enhance employers' welfare at the expense of workers' welfare. According to this view, the employers introduced company housing, corporate pension, and company unions to divide workers by firm and forestall trade unions to minimize labor's bargaining power. Brandes (1970) highlights the lack of employees' appreciation of corporate welfare, concluding that an "inequitable distribution of wealth and prerogative" under private welfare capitalism could not have been maintained indefinitely (p.146). The replacement of corporate welfarism by the welfare state and industrial unionism was inevitable, and thus, the Great Depression was certainly sufficient but far from necessary for welfare capitalism's decline, argues Bernstein (1960).

Other historians have claimed that the primary goal of private welfare capitalism was to achieve greater efficiency that would improve employees' welfare. According to this view, employers preferred company-level employee representation to trade unions because the former could facilitate employer-employee cooperation while the latter were "outsiders" with little understanding of firms' internal operation. Emphasizing the breadth and depth of corporate welfare programs in the 1920s, Brody (1980) contends that corporate welfarism might have prevailed had the Great Depression not hit the economy as strongly as it did (Chapter 2). In a similar spirit, Piore \& Sabel (1984) claim that the American industrial relations system that had emerged under the New Deal was neither necessary nor uniquely efficient, but rather a "historical accident" (p.113). As the depression challenged even the most resourceful and committed employers, the widespread failure to meet their promises led to disillusionment among their workers, observes Cohen (1990).

Was American private welfare capitalism a form of managerial domination destined to fail,

\footnotetext{
${ }^{1}$ E.g., Bernstein (1960), Brandes (1970), Brody (1980), Berkowitz \& McQaid (1980), Jacoby (1985), Zahavi (1988), Cohen (1990), Fairris (1997), Tone (1997).
} 
or was it a Pareto improving initiative that ended prematurely due to an extraordinary economic shock? The objective of this paper is to shed new light on the debate by introducing a gametheoretic analysis and a comparative perspective. First, using a methodology pioneered by Greif (1993), I apply insights from contract theory to examine the economic institution of private welfare capitalism. Based on historical observations, I redefine corporate welfarism as a set of personnel policies that could constitute an implicit contract equilibrium in repeated employeremployee interactions. The game-theoretic framework not only enables us, for the first time, to study the contractual nature of private welfare capitalism, but it also provides boundary conditions for its existence and efficiency, indicates potential complementarity among a diverse set of practices, and captures the role of expectations in an equilibrium selection as well as the importance of history in shaping expectations.

Second, I employ a comparative historical analysis, using Japan's experience in the 1930s as counterfactual evidence to that of the U.S. ${ }^{2}$ Private welfare capitalism was not uniquely an American phenomenon: most notably it was also seen in Britain, France, Germany, and Japan. But as noted by Jacoby (1993), among these countries, the U.S. and Japan shared more in common as the rise of corporate welfarism preceded the rise of welfare state and mass unionism in both countries. Japanese employers' conscious learning from contemporary U.S. practices also contributed to the similarity of corporate welfarism across the two countries. The differential magnitude of the Great Depression experienced by the two thus provides a natural experiment - albeit not ideal - for evaluating the impact of the economic shock on corporate welfarism and subsequent institutional developments. This is not to say that the employment systems in the U.S. and Japan were identical prior to 1929: it is to claim that employment practices pertaining to blue-collar workers in comparable sectors in the two economies were developing in parallel, converging to an implicit contract equilibrium in the 1920 s.

The historical analysis identifies the early 1930s as a bifurcation point at which the institutional trajectories in the U.S. and Japan began to diverge toward two distinct equilibria. In the U.S., despite their initial effort, the deep and prolonged depression induced a majority of welfare capitalist firms to renege on their corporate welfare practices pertaining to blue-collar workers. The repudiation of the implicit contract caused the change in expectations of both employees and

\footnotetext{
${ }^{2}$ See Chūma (1987) for an original insight.
} 
the public, which in turn supported the rise of union movements, adversarial labor-management relations, and the development of explicit and legally-enforceable employment contracts in place of implicit contracts. The initial unraveling of implicit contracts was reinforced by government legislation that changed "the rules of the game" for private players. I argue that the nature of the change was endogenous, reflecting the shift in the relative power of constituencies and the dominant beliefs in the society. By contrast, during a shorter and less severe depression, a majority of the proponents of corporate welfarism in Japan adhered to their implicit contracts, while developing institutional arrangements that would mitigate further negative impacts of business fluctuations. As the perception of employees and the public remained relatively appreciative of private welfare capitalism in Japan, the government intervention prompted by the depression resulted in labor legislations that endorsed corporate welfare provision and employee representation plans.

By the early 1940s, corporate welfarism in the U.S. and Japan began to take different contractual forms and enforcement mechanisms, foreshadowing distinct postwar industrial relations systems in the respective countries (Moriguchi (2000)). In the U.S., although corporate welfare programs pertaining to blue-collar employees were revived with the advent of WWII, discretionary benefit plans and company unionism were replaced by explicit contractual rights and industrial unionism. In Japan, although workers obtained greater bargaining power and legal rights immediately after the war, implicit and discretionary contracts and enterprise-wide unions continued to shape labor-management relations in major industrial concerns. The analysis thus indicates a path dependence in which the depression left a lasting impact on the subsequent institutional development.

The rest of the paper is organized as follows. Section 2 examines the economics of private welfare capitalism and introduces a theoretical framework. Section 3 establishes the comparability of the nature and prevalence of corporate welfarism between the U.S. and Japan in the 1920s. Section 4 documents the impact of the Great Depression, and Section 5 contrasts the endogenous transformation of labor laws in the two countries. To conclude, Section 6 discusses counterfactuals implied by a comparative analysis. 


\section{Economics of Corporate Welfarism}

\subsection{Historical Background and Three Economic Rationales}

Historians have documented employers' voluntary provision of non-wage benefits and services to factory workers in the U.S. since the early twentieth century (Bernstein (1960); Brandes (1970); Nelson (1975); Jacoby (1985)). The so-called "welfare work" became a nation-wide movement during WWI, as numerous firms introduced a variety of employer-sponsored programs in order to attract workers and preempt labor discontent. The early movement was often characterized by its paternalistic nature, piecemeal formulation, and erratic implementation (BLS (1913); Brandes (1970)), and many firms abandoned their programs once the postwar recession reversed the economic conditions (Nelson (1975), pp.100-7). Among the employers who had continued to experiment, however, corporate welfare programs matured into more sophisticated corporate programs with sounder financial bases and more impartial administration. ${ }^{3}$ Although union avoidance continued to be a strong motive, it became less important in the 1920s among major employers who emphasized economic efficiency. ${ }^{4}$ Distinguishing the latter movement from the earlier welfare work, I define corporate welfarism as a set of comprehensive personnel programs pertaining to blue-collar workers that developed after WWI.

The most comprehensive survey on corporate employment practices was conducted by the leading employers association, the National Industrial Conference Board, in 1928, covering over 6,000 industrial establishments (NICB (1929)). As Table 1 shows, larger establishments were more likely to have any given program, but even among the large plants with more than 250 workers, only a minority of them instituted these programs. The NICB study listed a wide variety of personnel programs, extending from non-wage benefits to training and education, health and safety, housing and dining, social and recreational activities, and employee relations programs. Contemporary scholars, as well as historians, saw little coherence among diverse personnel activities and made little attempt to examine their interrelations. Bureau of Labor Statistics officials defined personnel work as "anything for the comfort and improvement, intel-

\footnotetext{
${ }^{3}$ These employers included Bethlehem Steel, Du Pont, Eastman Kodak, General Electric, General Motors, Goodyear Tire \& Rubber, International Harvester, Procter \& Gamble, Standard Oil of New Jersey, and U.S. Steel.

${ }^{4}$ Slichter (1929); NICB (1931); Hicks (1941), p.43 and p.108; Berkowitz \& McQaid (1980), p.56; Jacoby (1985), p.159; Cohen (1990); Kaufman \& Taras (2000), p.39.
} 
lectual or social, of the employees, over and above wages paid, which is not a necessity of the industry nor required by law," or as Bernstein simply puts it, it was the "congeries of policies" embracing numerous features (BLS (1913); Bernstein (1960), p.174). Why did some employers offer a variety of non-wage benefits and services to their blue-collar workers beyond legal obligation? Why did employers, rather than markets, supply them? Could these programs generate returns greater than their costs? In addition to the managerial domination theory, I consider three economic rationales for corporate welfarism. ${ }^{5}$

First of all, incomplete markets may give firms an advantage in providing these services. For example, when financial markets are incomplete, firms may profit by offering their employees risk sharing and consumption smoothing in the form of life insurance, accident benefits, savings plans, and housing loans. Similarly, employers may have an advantage over markets in providing location-specific goods, such as medical services, safety education, on-the-job training, and recreational activities. Other non-market institutions, most notably governments and unions, could and did supply some of these services, but the relative absence of the welfare state and the limited reach of trade unionism prior to the 1930s gave American employers a substantial first-mover advantage (Berkowitz \& McQaid (1980)). When employers were indeed a more efficient provider of the goods than markets, they could either charge premiums to their employees or lower wages by an equivalent amount (i.e., compensating wage differentials) to reap profits from these activities. ${ }^{6}$

Although the incomplete market hypothesis seems to fit well with historical observations, it leaves some contractual features unexplained. First, evidence indicates that, although there certainly were cases in which benefits were substitutes for wages, most welfare capitalists were leading manufacturing employers who provided benefits and services at substantial discounts, if not free, to employees and paid wages that were above industry and regional averages (BLS (1928)). Second, as elaborated below, company records reveal that in most benefit plans the amount of the benefit was made contingent on employees' characteristics. If employers were simply substituting for markets, why would they leave positive rents to employees and distribute the rents according to employee characteristics? Third, the incomplete market hypothesis would

\footnotetext{
${ }^{5}$ For related work, see Fishback (1992) for corporate welfarism in coal mining and Alston \& Ferrie (1999) for agricultural paternalism.

${ }^{6}$ See Fishback \& Kantor (1995) for compensating wage differentials in the context of workers' compensation.
} 
not explain the adoption of such programs as company picnics, centralized employment, and employee representation plans, which were often simultaneously introduced.

An alternative hypothesis is suggested by implicit contract theory (MacLeod \& Malcomson (1989)). According to the theory, employers may offer efficiency wage or performance pay to employees contingent on the level of non-contractable effort, i.e., effort that is observable within an organization but unverifiable to a third party (Shapiro \& Stiglitz (1984); Baker, Gibbons \& Murphy (1994)). ${ }^{7}$ Employers have an incentive to design such an implicit contract if greater employee effort generates positive returns after compensating for the disutility of effort. However, since an implicit contract is by definition not legally enforceable, it requires internal enforcement mechanisms that compel both employers and employees to conform to the proposed contractual terms. The hypothesis thus indicates that management may install enforcement institutions together with pecuniary benefit plans.

Many of the corporate programs, such as pension and stockownership plans, however, promised benefits that would accrue over a long time period. Why did employers offer long-term contracts to their factory workers? In contrast to static efficiency wage theory, human capital theory provides the reasons for dynamic contracting. It indicates that employers may design long-term contractual arrangements, such as employment guarantee, internal promotion, seniority wages, and deferred compensation, to encourage employees to acquire desirable human capital and to reduce employee turnover (Lazear (1979); Prendergast (1993); Kanemoto \& MacLeod (1989)). The human capital hypothesis predicts that the rise of systematic corporate training would be accompanied by a set of long-term incentive contracts.

\subsection{The Contractual Nature of Corporate Welfarism}

The above three hypotheses are theoretically distinct but not mutually exclusive. ${ }^{8}$ I first examine the nature of corporate programs using qualitative evidence, and then develop a theoretical framework which is based on implicit contract theory with non-contractable employee human capital. For clearer exposition, I divide personnel programs into three categories, (a) long-term

\footnotetext{
${ }^{7}$ An implicit contract is defined as a contract that is not legally-enforceable, and an explicit contract is defined as a contract that is legally enforceable.

${ }^{8}$ Although the relative importance of the three rationales in motivating welfare capitalists is an important empirical question, differentiating these hypotheses requires far better data than are available and is beyond the scope of this paper.
} 
incentive contracts, (b) human capital investment, and (c) internal enforcement mechanisms, in the following discussion.

Historical evidence indicates that a central element of corporate welfarism was a long-term incentive contract that offered benefits and services contingent on employees' firm-specific tenure and other characteristics such as merit, workmanship, loyalty, and reliability. Corporate records reveal that many personnel programs exhibited this contractual feature: retirement pension, supplementary bonuses, group insurance, accident and sickness benefits, profit sharing plans, stock ownership plans, savings and investment plans, paid vacations, housing loans, internal promotion, and, in some cases, medical services. In these programs, an amount of benefits received by employees was defined as an increasing function of employee's length of service, while management retained the right to grant, withhold, reduce or terminate the benefits in individual cases. ${ }^{9}$

As emphasized by contemporary management, the provision of benefits surpassed the legal obligations specified by state-level workers' compensation laws. Moreover, both employee's tenure and characteristics were non-contractable variables because any employment contracts longer than one year were not enforced by court under the employment-at-will principle, whereas the characteristics such as "workmanship" and "loyalty" were non-verifiable to a third party. Thus, private welfare provision was based on an implicit contract that conferred no legal rights upon employees, and therefore management could modify or abandon them if so desired with legal impunity (BLS (1919), p.11; BLS (1928), p.74). ${ }^{10}$ In the words of contemporary economist John R. Commons, even though employers often made pledges not to renege on the plan once it was granted, that promise "rested on the integrity of the company alone" (Commons, Lescohier

\footnotetext{
${ }^{9}$ At International Harvester, its pension plan specified the amount of annual payment based on the years of service and wages, while stipulating that its establishment "shall not be held as creating a contract or giving to any employee a right to be retained in the service or any right to a pension" (Annual Report (1922); Ozanne (1967), p.83). At Endicott Johnson, upon offering company homes on liberal terms, employment officers took charge of selecting qualified buyers to insure the only "desirable" workers with more than five years of service and good employment records would be considered (Zahavi (1988), p.47). At General Electric, employees received one week of paid vacation after 3 years of continuous service and two weeks after 10 years of service; management also provided free life insurance starting from $\$ 500$ up to $\$ 1,500$ depending on an employee's length of service and employment records.

${ }^{10} \mathrm{~A}$ number of law suits were filed against management by employees who were disqualified from or denied payments in profit-sharing and pension plans. The courts consistently ruled in favor of companies on the ground that, since these benefits were mere gratuities on the part of employers, management had the sole right of determining the conditions under which they should be paid. For early rulings, see BLS (1919), p.6.
} 
\& Brandeis (1935), pp.338-9).

In the second category, human capital investment, a number of leading employers introduced two- to five-year corporate apprenticeship courses, combining on-the-job training and in-class instructions. Apprenticeship wages were set low and employees who had proved "meritorious" received job offers from their employer with higher wages upon graduation. The long-term human capital investment was tied to a policy of internal promotion, which offered career prospects to production workers based on their merits, skills, and seniority. ${ }^{11}$ Major employers also offered safety and health education, disseminated practical information through employee magazine and pamphlets, and set up a library for employees with general and technical references. Safety committees were introduced not only to educate employees in accident prevention, but also to encourage their initiative in eliminating hazardous working conditions. To utilize human capital at the shop floor, some employers established a formal suggestion system with monetary awards soliciting suggestions for efficiency improvements from blue-collar employees. ${ }^{12}$

With respect to the third category, the internal enforcement mechanisms, evidence suggests that employers were generally concerned about the negative impact on employee morale, possible labor disputes, and future recruitment that the termination of corporate benefits might trigger. Management argued that the best way to prevent labor conflicts was to build up a corporate reputation for fair dealing and consideration of the interest of employees (NICB (1931), p.13). At Kodak, a famous profit-sharing plan was maintained despite changes in business conditions, as management was afraid that "employees would misunderstand such a change and feel that Kodak had reneged on a deal" (Jacoby (1997), p.79). At Endicott Johnson, managers felt that they could not abandon their corporate welfarism "for fear of violating the explicit and implicit expectations" it had created among employees (Zahavi (1988), p.143). Leading employers were keenly aware that even though management could exercise its discretion in adopting a personnel policy in the absence of state regulations, it was public opinion that would exercise compulsion (NICB (1931), pp.15-8).

To facilitate internal enforcement, welfare capitalists instituted various personnel programs

\footnotetext{
${ }^{11}$ For instance, at DuPont, General Electric, General Motors, Goodyear, and Western Electric, corporate education programs functioned as a means to identify and foster potential supervisory personnel (Allen (1943); Rumm (1989), p.360; Nelson-Rowe (1991); Young \& Tuttle (1969); Schacht (1975), p.14).

${ }^{12}$ At Goodyear and other firms, employees' suggestions on workplace organization and machine improvement led to an increase in productivity and improvement of product quality (Nelson (1982); Fairris (1997)).
} 
promoting communication, coordination, and employee involvement. To establish commitment, management formalized welfare programs and announced their rules, regulations, and operations through bulletin boards, employee handbooks, and employee magazines. At Standard Oil of New Jersey, for example, management distributed a printed labor policy to all employees so that "every worker can always hold the company to its promised word" (Chase (1947), p.20). An increasing number of employers set up benefit funds, committing corporate resources ex ante to meet future obligations. To facilitate bilateral communication and employee participation, leading employers set up suggestion systems, joint committees, and employee representation plans. To ensure fair and consistent implementation, personnel policy was increasingly formed at the corporate-level and personnel administration was centralized at a personnel department. ${ }^{13}$ Coordinating employees' expectations and promoting “coöperative” employer-employee relations were also important. To build employee loyalty and corporate identity, many employers sponsored or assisted a wide variety of recreational activities and signaled their goodwill. Company picnics, dance parties, employee clubs, and athletic teams, which involved employees and their families, were regularly featured in employee magazines.

Furthermore, leading employers incorporated some form of joint administration in operating welfare programs. The most formal expression of it was the adoption of an employee representation plan (ERP), also known as "company union." Under the plan, employee representatives would be elected from among blue-collar employees and regularly meet with management representatives to discuss matters of mutual concern, including corporate welfare programs. As correctly criticized by labor historians, ERPs were by no means collective bargaining units comparable to trade unions, as they were financially dependent on management and given only advisory power over limited subject matters. Nevertheless ERPs provided regular forums for employeremployee communication and information sharing that previously had been non-existent. ${ }^{14}$ The

\footnotetext{
${ }^{13}$ To provide coordination within managerial ranks, top management instituted foremen training courses in an effort to check foremen's decisions over hiring, firing, and promotion that could undermine the corporate policy for their often-noted arbitrariness and injustice. The personnel department compiled employee records, including attendance, wages, length of service, and reasons for separation, which were essential in monitoring the behavior of blue-collar employees as well as foremen.

${ }^{14}$ For instance, some employers noted that ERPs were used not only to communicate the details of personnel policies but also to judge if these policies were successfully implemented; others observed that ERPs became educational opportunities for both management and employees as they discussed various aspects of the plant operation (Houser (1927), pp.15-20). At Bethlehem Steel, General Electric, and Standard Oil of New Jersey, a considerable number of grievance cases brought by their ERPs were settled in favor of workers (Slichter (1929),
} 
plans also gave employees opportunities to participate in discussing personnel programs, voice their concerns, and form collective opinions, and as such, once introduced, employers were often surprised by the amount of managerial time and commitment their ERPs required (Nelson (1982); Ozanne (1967)).

Lastly, company-specific evidence suggests that, at least in a number of instances, corporate welfarism became a mutually binding commitment between an employer and employees as a result of their strategic interactions. For example, Zahavi (1988) describes the corporate welfarism at Endicott Johnson as follows (p.105):

Although the workers expressed loyalty to the corporation, they repeatedly demonstrated that their loyalty has limits and it had to be reciprocated by management. Workers developed formal and informal strategies for extracting and expanding managerial obligations $[\ldots]$. The [corporate welfarism] became an autonomous reference point and an independent code of just behavior, which allowed workers to judge corporate policies and actions and which entrapped management.

\subsection{Theoretical Framework: Implicit Contract Analysis}

Based on the above observations, I characterize corporate welfarism as a set of employment practices that constitutes an implicit contract equilibrium in a repeated employment game. ${ }^{15}$ More specifically, I consider a repeated game between an infinitely-lived firm and over-lapping generations of workers each of whom lives for two periods. I assume that each worker can invest in human capital with a cost that will increase his labor productivity one period later. Human capital, however, is non-contractable as it incorporates establishment-specific skills and knowledge that are unverifiable by a third-party. To induce human capital investment, an employer may offer an implicit contract to a young worker that provides an employment guarantee for two periods and promises extra compensation in the second period contingent on his human capital acquisition.

Under which conditions can this implicit contract be self-enforcing? Based on the historical observations, I assume reputation as a primary enforcement mechanism in which the employer's

p.413; Schacht (1975); Gray \& Gullett (1973)).

${ }^{15}$ A theoretical appendix is available from the author upon request; see Moriguchi (2001) for a formal analysis. 
breach of the contract will cause current and future employees to withdraw cooperation by, for example, choosing the low level of effort, not investing in human capital, and joining outside unions. As is well-known, the self-enforcement condition requires that the employer's gain from appropriating extra compensation be smaller than the present value of the future losses resulting from such appropriation. ${ }^{16}$ I focus on two particular subgame perfect Nash equilibria of the repeated game that resemble spot contracting and corporate welfarism. The Spot Contract Equilibrium (SCE) is characterized by a short-term employment contract and high labor turnover; low level of human capital; the same basic wage paid in every period; and low labor productivity. By contrast, the Implicit Contract Equilibrium (ICE) is characterized by a long-term implicit employment contract and low labor turnover; a higher level of human capital; extra compensation paid in the second period in addition to the basic wage; higher labor productivity; and internal enforcement based on reputation. Note that the ICE is supported by a set of reciprocal expectations in which an employer expects workers to acquire desirable human capital and workers expect the firm to reward such investment when it materializes.

The above model generates implications that are consistent with the qualitative evidence presented above and useful for further historical investigation.

1) Complementarity: the theory indicates that internal enforcement mechanisms are an integral part of the ICE, suggesting complementarity among seemingly unrelated programs. Observe, for example, that an effective reputation mechanism requires not only workers' ability to monitor management behavior but also sufficient information transmission among workers within an establishment. ${ }^{17}$ In contrast to a common view that the firm always benefits when it can "divide and conquer" workers, the model indicates that the firm may have an incentive to facilitate coordination among employees and empower them to a certain degree to establish credible commitment.

2) Existence $\&$ Efficiency: according to the model, the ICE outcome is always Pareto superior to the SCE outcome. Why then did all firms not use implicit contracts? The self-enforcement condition implies that a firm can establish credible commitment only if its time discount factor is higher than a given threshold. The threshold discount factor is increasing in the size of

\footnotetext{
${ }^{16}$ See, for example, Baker et al. (1994).

${ }^{17}$ For a similar point, see Greif, Milgrom \& Weingast (1994).
} 
compensation and decreasing in the returns from human capital investment and the quality of internal enforcement. If smaller firms are less financially stable and have a shorter time horizon, the condition implies that smaller firms are less likely to adopt implicit contracts, which is consistent with the evidence. The model further indicates that the ICE is vulnerable to economic fluctuations while the SCE is not. If a recession exogenously increases a firm's probability of bankruptcy and lowers its discount factor below the threshold, management will no longer maintain its implicit contract; if the discount factor remains above the threshold, however, management keeps the contract. This implication is explored in Section 4.

3) Multiple Equilibria \& Coordination: the existence conditions for the equilibria imply that when the ICE exists the SCE also exists. In the presence of multiple equilibria, management cannot unilaterally "select" an equilibrium as its realization will depend on workers' expectations. If workers believe that the firm would not honor its implicit contract, the ICE unravels and degenerates to the spot contracting outcome, self-fulfilling the workers' original expectations even if the ICE is more efficient. In other words, the two competing views of welfare capitalism (managerial domination vs. efficiency improvement) emerge as equilibrium beliefs associated respectively with the SCE and ICE in this model. This observation has two implications. First, the coordination of expectations can be crucial in implementing the ICE. Although the formal theory remains silent on how to achieve coordination, the evidence reviewed above suggests that socialization, recreation activities, and bilateral communication could play an important role in signaling employers' goodwill and fostering mutual trust. Second, if workers have incomplete information over their firm's true type, once one of the two views becomes dominant in the economy, the self-fulfilling nature of the belief may generate an externality that drives all firms in the economy to converge to one equilibrium. This implication is explored in Section 5.

4) The Rise of the Explicit Contract Equilibrium: the model can be extended to show that after the breakdown of the ICE and the reversion to the SCE, management and labor may advance an alternative contractual arrangement based on third-party enforcement. That is, in the presence of mutual distrust, the employer and workers may agree to develop contractable "proxies" for non-contractable human capital and write a detailed and legally-enforceable contract contingent on the proxies. The resulting equilibrium, the Explicit Contract Equilibrium (ECE), can achieve higher efficiency than the SCE. 


\section{Corporate Welfarism in the U.S. and Japan in the 1920s}

How prevalent was corporate welfarism in the U.S. prior to the Great Depression? Was the movement in Japan comparable to that in the U.S. in its contractual nature as well as in its prevalence? To address these questions, I present quantitative evidence using contemporary surveys in the respective countries.

\subsection{Corporate Welfarism in the U.S., 1920-29}

Although corporate welfarism, defined as a set of comprehensive personnel programs, was confined to a minority of large employers in the U.S. during the 1920 s, it was a sizable minority representing a growing trend. At the end of the decade, several hundred large American establishments practiced corporate welfarism, employing roughly 15 to 20 percent of production workers in the U.S. Corporate expenditures on these programs were not trivial.

Two detailed studies by the BLS, which were conducted in 1917 and 1926 on overlapping samples of 430 large plants, documented a trend in corporate welfarism among American firms (BLS (1919, 1928); Fairris (1997), p.33). Despite the setback during the post-WWI recession, the studies recorded a net increase in the number of establishments adopting major corporate program between 1917 and 1926. Most notably, the percentage of establishments having group insurance plans had increased from $7 \%$ to $43 \%$; disability benefit funds from $19 \%$ to $50 \%$; paid vacation plans from $4 \%$ to $37 \%$; employee classes from $17 \%$ to $33 \%$; and recreational facilities from $35 \%$ to $55 \%$. The percentage of establishments instituting joint administration of personnel programs rose to $80 \%$ from $46 \%$. Although not covered by the BLS studies, the number of firms with formal retirement pension plans in the U.S. had more than doubled between 1915 and 1926 to 370 firms covering 4 million white- and blue-collar employees; the number of firms adopting ERPs had increased from 145 to 399 between 1919 and 1928, covering more than 1.5 million production workers (see Table 2); and the number of firms with stockownership plans for all employees had doubled between 1921 and 1927 to about 280 firms. ${ }^{18}$

According to the 1926 BLS study, consistently over 30 percent of the 430 establishments surveyed adopted major personnel programs, e.g., group life insurance, sickness and disability

\footnotetext{
${ }^{18}$ NICB (1925b); Epstein (1926); NICB (1925c); NICB (1933); NICB (1928b). The number of companies having profit sharing plans, by contrast, is likely to have declined during the 1920s (BLS (1917); BLS (1928)).
} 
benefits, paid vacations, medical services, employee education, recreation and socialization, and joint administration (BLS (1928)). According to the aforementioned 1928 NICB survey, consistently over 20 percent of 1,676 large plants implemented major programs (see Table 1). What cannot be inferred from these studies, however, is a distribution of personnel programs across firms. Were these programs uniformly distributed or clustered to a small set of firms? Unfortunately, no micro-level data are available to test the correlations among different programs adopted; however, company-level evidence suggests that large establishments tended to adopt a set of comprehensive programs "en bloc," combining financial incentives, corporate training, centralized personnel management, and some form of employee participation (Jacoby (1985), p.118; Moriguchi (2002)). ${ }^{19}$ If the positive correlations are assumed, Table 1 indicates that there were 400 to 600 establishments in the U.S. adopting relatively comprehensive personnel programs at the end of the 1920s.

How costly was it to implement corporate welfarism? A 1923 study by the American Management Association found the average expense for personnel activities of 90 firms to be $1.53 \%$ of total annual payroll; the 1926 BLS study found the average welfare expenditures of 190 companies to be $\$ 27$ or about $2 \%$ of wage earner's annual payroll; the 1928 NICB study found the average of approximately 400 small establishments to be $\$ 26.65$ or about $2 \%$ of annual factory payroll; and a 1933 NICB study found the median cost of some 70 large establishments to be $\$ 14.06$ or $1.85 \%$ of payroll. ${ }^{20}$ These observations led Jacoby (1985) to conclude that, "despite the high-minded rhetoric that accompanied it, few companies spent enough [...] to have had a widespread effect on worker loyalty or economic security" (p.199). The same data, however, also indicate considerable inter-firm variation; the 1926 BLS study reported the cost ranging from $\$ 14$ to $\$ 120$ among the sample establishments and the 1933 NICB study from $\$ 1.36$ to $\$ 175.40$. To assess the cost of implementing comprehensive welfare programs, I estimate the corporate expenditures on fourteen personnel program for which data are available (see Table 3). ${ }^{21}$ The most expensive program was profit sharing, followed by supplemental bonuses and

\footnotetext{
${ }^{19}$ A 1923 study by the American Management Association, which surveyed 90 plants on 10 personnel activities, found that plants with more than 1,500 employees had adopted on average 7.7 personnel activities, whereas plants with less than 500 employees had adopted only 2.2 activities (AMA (1925)).

${ }^{20}$ AMA (1925); BLS (1928); NICB (1929); NICB (1934).

${ }^{21}$ AMA (1925); NICB (1925a); NICB (1928a); NICB (1929); NICB (1934); Epstein (1926); BLS (1927); BLS (1928).
} 
paid vacations. Table 3 indicates that, if a firm adopted all of the fourteen programs listed, total cost would have been $12 \%$ of annual payroll. When less prevalent programs (i.e., profit sharing and supplemental bonuses) were excluded, the welfare expenditures would have been about $6 \%$ of payroll. ${ }^{22}$

\subsection{Corporate Welfarism in Japan, 1920-29}

The growth of corporate welfare programs pertaining to factory workers $(\operatorname{shokk} \bar{o})$ in Japan in the early twentieth century is relatively well-documented (Hyōdō (1971); Hazama (1978); Gordon (1985)). Early welfare work, referred to as "keiei onjō shugi" or employer paternalism, was often erratic, short-lived, and an inferior substitute for wages. With the rapid growth of capitalintensive manufacturing industries, however, corporate welfarism in Japan matured into more systematic and substantive programs after WWI (Kyōchōkai (1929), Chapter 18). ${ }^{23}$ By the end of the 1920s, a few hundred Japanese establishments adopted fairly comprehensive personnel programs. However, the movement in Japan was also confined to leading employers, covering no more than one-fifth of the nation's production workers.

The only available survey on corporate welfare practices in the 1920s was by the semi-public research institution Kyōchōkai in 1921, which covered 157 large private plants employing 300 or more workers. As Table 4 shows, major employers instituted retirement pension plans, sickness and death benefits for employees and their families, length-of-service bonuses, profit sharing bonuses, stock ownership plans, savings plans, company housing, and medical services for their blue-collar workers, all of which surpassed minimum legal requirements. ${ }^{24}$ Table 4 also reports the findings of the 1932 survey by the Social Bureau of the Home Ministry, covering 2,310 private plants with 100 or more workers. ${ }^{25}$ Similar to American corporate welfarism, these corporate programs were implicit contracts that conferred no legal rights upon employees, and

\footnotetext{
${ }^{22}$ Note that no data are available for stock ownership plans, savings plans, and ERPs. As evidence suggests that these were relatively costly plans, the average expenditures could be higher if a firm adopted these plans.

${ }^{23}$ Large zaibatsu-affiliated firms in heavy industries, such as Hitachi Engineering Work, Ishikawajima Shipyards, Mitsubishi Electric, Mitsubishi Shipyards, Nippon Steel, Ōji Paper, Onoda Cement, Shibaura Engineering Work, Sumitomo Electric Wire, were the major proponents of corporate welfarism.

${ }^{24}$ The 1926 Revised Factory Law mandated fourteen days wages as a severance pay in the case of dismissals due to business reasons and the 1928 Health Insurance Law obligated employers to provide injury, sickness, and death benefits.

${ }^{25}$ Kyōchōkai (1924); Shakaikyoku (1933); Shakaikyoku (1934). To maintain comparability with the U.S. data, government-owned plants are not included in Table 4.
} 
management retained the right to change or deny benefits on an individual basis depending on employee characteristics. ${ }^{26}$ A typical retirement allowance plan (taishoku teate seido), the equivalent of a lump-sum pension and dismissal compensation combined, specified the amount of allowance paid upon separating from a company contingent on an employee's length of service, age, and the reason for separation. ${ }^{27}$

To encourage human capital investment, major Japanese employers set up formal training programs for employees as well as supplemental education programs, lectures, and company libraries. In particular, leading manufacturing employers instituted corporate schools (shokk $\bar{o}$ gakkō) to foster skilled and semi-skilled employees in-house rather than relying on public schools, and adopted a policy of internal promotion (Hyōdō (1971), p.407; Hazama (1978), p.513). Uraga Dock, for example, offered a corporate apprenticeship contract that specified a three to five year training period with periodic wage raises and compulsory savings, which would pay out the savings and interest only if the apprentice completed the training and stayed with the company for five years afterwards (Hyōdō (1971), p.407; Gordon (1985), pp.103-6). At Mitsubishi Shipyards and Hitachi Engineering Works, employers established corporate schools and gradually reduced mid-career hiring in favor of workers who graduated from company training programs (Hazama (1978), p.513).

Japanese management also sponsored various recreational and social activities including company picnics, field days, motion pictures, and athletic competitions, and promoted the spirit of employer-employee cooperation. Many major enterprises established personnel sections and personnel managers were put in charge of careful screening for hiring new workers, enforcement of work discipline, evaluation of employees, and administration of personnel programs. ${ }^{28} \mathrm{~A}$ growing tendency toward employee involvement was also seen among Japanese establishments. An increasing number of employers established mutual aid associations, ERPs (typically called "kōjo iinkai" or factory councils), or less formal employee organizations, through which factory employees took part in administrating corporate welfare programs (Kyōchōkai (1929), pp.912-3).

\footnotetext{
${ }^{26}$ See Hyōdō (1971), pp.327-9; Hazama (1978), p.521; Sumiya (1966), p.135. For example, in introducing seniority bonuses for factory workers, Nippon Steel required employees not only to have a minimum five years of service but also to be deemed "diligent, loyal, and decent-mannered" by management; at Mitsubishi Shipyards, management retained full authority to determine the number of workers receiving a pay raise as well as the amount of the raise, based on merit, skill, and diligence of individual employees.

${ }^{27}$ Kyōchōkai (1924); Zensanren (1932), p.5; Shakaikyoku (1936), pp.61-2.

${ }^{28}$ Hazama (1978), pp.512-3; Shōwa Dōjin-kai (1960), p.274; Hyōdō (1971), pp.436-7; Gordon (1985), p.110.
} 
As in the U.S., ERPs were only a consultative body whose primary objective was to facilitate communication and build trust between employers and employees. In most ERPs, management in the beginning tried to confine the agenda of council meetings to the enhancement of workers' welfare and productivity. Once introduced, however, ERPs gave workers some voice in formulating personnel policies. ${ }^{29}$ As corporate programs became more permanent institutions, many large companies established welfare funds for their employee benefit plans and committed corporate resources to improve financial soundness in the 1920s (Kyōchōkai (1924); Gordon (1985), pp.110-4; Kyōchōkai (1929), pp.910-2).

The similarity between private welfare capitalism in the U.S. and Japan was often a result of direct and indirect learning. Major employers in both countries learned from British and German precedents, and leading Japanese employers studied American practices as a possible role model. For example, a researcher at Mitsubishi was sent to the U.S. specifically to collect data on corporate personnel policies. A manager at Sumitomo Electric Wire established ERPs modeled after International Harvester and Standard Oil plans after visiting American firms. The BLS and NICB studies were closely followed by contemporary Japanese scholars and bureaucrats. ${ }^{30}$

How prevalent was corporate welfarism in Japan? Although available quantitative data in the 1920s are limited, evidence suggests that the movement in Japan was also confined to a minority of leading firms consisting of 200 to 300 establishments. According to Table 4, in 1932, consistently over 200 plants adopted major incentive contracts, training programs, socialization activities, and joint administration and other forms of employee involvement. Yet, only 112 establishments in Japan had ERPs in 1929, and only 132 out of 256 large establishments surveyed had formal retirement allowance plans in 1930 (Kyōchōkai (1932)). In the late 1920s, there were about 200 private establishments employing 1,000 or more workers in Japan, which together employed approximately 400,000 workers or 20 percent of total production workers. Although

\footnotetext{
${ }^{29}$ At Sumitomo factories, workers protested when management refused to discuss subjects proposed by employee representatives concerning standards for awarding supplementary bonuses, changes in incentive wages, and revision of the retirement allowance plan. Eventually, management conceded to include those issues as subjects for consultation. Similarly, at Mitsubishi Shipyards, three years after the introduction of its ERP, management allowed basic working conditions to be discussed at the ERP meetings in response to growing employees' demand (Hazama (1978), p.532; Hyōdō (1971), pp.399-402). At Uraga, as its mutual aid society gave workers control over a part of welfare programs, what management once thought of company benevolence became "the fulfillment of a company obligation" to its workers (Gordon (1985), p.113).

${ }^{30}$ Kyōchōkai (1920); Kyōchōkai (1921); Mitsubishi Gōshi (1921); Kyōchōkai (1929), Chapter 9; Mimura (1930); Zensanren (1932a).
} 
these establishments did not entirely coincide with the set of welfare capitalists, since there was a significant overlap, I use 20 percent as an upper bound for the percentage of workers employed by welfare capitalists in Japan. The data on welfare expenditures were reported in a 1926 survey by a leading employers' association, Japan Industrial Club (NKK (1928)). The average expenditures on personnel programs of 62 leading companies were 32.41 yen or 10.7 percent of the annual payroll. In textiles and mining, however, the expenditures exceeded 20 percent of factory payrolls due to substantially lower wages paid in these industries. If these two industries are excluded from the sample, the average corporate expenditures on personnel programs were 7.9 percent of the annual payroll.

In summary, at the end of the 1920s, in both the U.S. and Japan, corporate welfarism was confined to a small set of large establishments in capital-intensive industries, covering no more than 20 percent of production workers. In other words, the nature of corporate welfarism and its prevalence in the economy in the late 1920s were roughly comparable between the U.S. and Japan.

\subsection{The Impact of Corporate Welfarism in the 1920s}

Toward the end of the decade, the two countries experienced common trends that were attributed to the diffusion of corporate welfarism by contemporary observers. First, as Figure 1 shows, labor turnover of factory workers declined in the 1920s in both countries. In the U.S., both aggregate-level data and company-level evidence indicate a statistically significant decline in turnover rates in the 1920s. ${ }^{31}$ Although aggregate-level data for Japan are less reliable and unavailable before 1923, combined with regional surveys and establishment-specific evidence, the data indicate a decline in labor turnover of Japanese workers during the $1920 \mathrm{~s} .{ }^{32}$

Second, the union movement in large establishments subsided in the 1920s in both countries. In the U.S., the number of work stoppages remained low after 1922 despite economic prosperity. Union membership fell by 14 percent between 1922 and 1928 to 3.5 million, while the number of employees covered by ERPs doubled to 1.5 million (Table 2). After examining corporate welfare practices, a contemporary leftist warned in 1927 that the trade unions in this country

\footnotetext{
${ }^{31}$ Berridge (1929); Sundstrom (1986), Chapter 3; Owen (1995a); Owen (1995b); Whatley \& Sedo (1997).

${ }^{32}$ NRUS (1959), II-60; Hyōdō (1971), p.405; Sumiya (1966), p.132; Odaka (1984), p.205; Nishinarita (1988), p.327.
} 
face in these practices a challenge to their very existence (Dunn (1927)). In Japan, although union membership increased steadily and the number of labor disputes remained relatively high throughout the 1920s, the center of the union movement shifted to small establishments by the end of the decade. In both the U.S. and Japan, despite repeated organization drives by existing unions, leading manufacturing establishments remained unorganized in the twenties (Bernstein (1960); Komatsu (1971)). Major proponents of corporate welfarism in the respective countries claimed that the low turnover, stable workforce, and labor-management cooperation were the result of their personnel policies. Although causal relations are difficult to establish and are in dispute (Jacoby (1985); Gordon (1985)), the above trends lent credibility to private welfare capitalists in the eyes of contemporaries.

Lastly, even though corporate welfarism was confined to a minority of employers in the U.S. and Japan, since its leading proponents were industry leaders, they had substantial political influence in both countries. In the U.S., starting as a secretary of commerce, Herbert Hoover became a promoter of "voluntarist corporatism" endorsing private welfare capitalism (Hawley (1979), p.68; Fausold (1985), pp.119-120). Similarly, in Japan, the zaibatsu leaders had close ties with politicians or were themselves members of the Diet. The governments in the respective countries supported private initiatives in industrial welfare and took a stance against trade unionism. In short, private welfare capitalism enjoyed growing political, intellectual, and social support during the 1920s in the respective countries (Berkowitz \& McQaid (1980); Garon (1988)).

\section{The Challenge of the Great Depression}

Among industrialized nations, the U.S. experienced the deepest and longest Great Depression while Japan experienced one of the mildest. U.S. industrial production fell by 50 percent in 192932 and did not fully recover to the 1929 level for over a decade; by contrast, Japan's industrial production declined by less than 10 percent in 1929-31 and returned to the pre-depression level by 1933 (Figure 2). Consistent with the theoretical prediction, during the initial years when the depression was less severe, business leaders in both countries tried to maintain their implicit contracts. However, the difference in the magnitude and duration of the depression eventually led to divergent responses of American and Japanese employers, resulting in the bifurcation of 
institutional trajectories in the two countries.

\subsection{The Great Depression and Broken Promises in the U.S.}

For the first two years of the depression in the U.S., the proponents of corporate welfarism made a considerable effort to keep their promises, expecting that the depression would soon end. Supporting employers' private effort, the Hoover administration urged business leaders not to reduce wages and promoted a national "share-the-work" movement to prevent mass unemployment. In contrast to today's U.S. corporate practices, in an effort to protect their workforce, major companies ceased hiring, reduced hours, transferred employees to different departments, and cut executive salaries (NICB (1930), p.36; Balderston (1933), p.261). International Harvester, for instance, instituted a policy to produce goods beyond present demand to create extra work (Ozanne (1967), pp.141-6). Western Electric reported in 1931 that shortened hours made it possible to retain all employees with "long service and experience" (Annual Report (1931), p.9). Leading firms also sponsored company relief programs, such as food baskets, cash loans, and rent subsidies for their employees.

The economy, however, continued to deteriorate: by late 1931, industrial production was 30 percent below the 1929 level, while tight monetary policy and multiple bank crises imposed serious liquidity constraints on firms (Friedman \& Schwartz (1963); Hunter (1982)). In the fall of 1931, major business leaders announced wage reductions. In June 1932, the level of industrial production was 60 percent below its 1929 peak, and the stock price index declined by more than 70 percent. By 1933 a majority of the proponents of corporate welfarism repudiated their implicit contracts, not only by withdrawing corporate benefits at the "time of the employees' greatest need," but also by implementing large-scale dismissals despite their earlier pledge to provide employment security in exchange of reduced work hours (Schatz (1983), p.61).

According to an NICB study that surveyed 233 establishments in 1934, personnel programs that showed the highest rate of discontinuation were: employee stock ownership (52\%), employee magazines (49\%), paid vacation for wage earners (43\%), social and recreational activities (38\%), profit sharing (35\%), corporate training (26\%), home purchase plans (24\%), and suggestion

systems (18\%) (NICB (1934)). By contrast, a low rate of discontinuation was reported in pension plans $(6.8 \%)$, ERPs $(5.7 \%)$, safety committees $(3.4 \%)$, centralized employment $(2.2 \%)$, 
and group life insurance (1.2\%). As Fairris (1997) points out, the findings do not support the often-held claim that private welfare capitalism fell apart during the depression. Nevertheless, his conclusion that its basic structure remained "largely intact" also calls for reassessment (p.61). The NICB survey likely understates the impact of the depression on corporate welfarism in at least three ways: first, the sample is biased towards very large establishments employing on average over 2,000 workers; second, company records indicate that downward revision and temporary suspension of welfare plans, which were unreported in the survey, were more prevalent than discontinuation (Moriguchi (2002)); and lastly, even if plans were in operation, the number of eligible workers fell drastically as most firms resorted to massive layoffs by $1932 .{ }^{33}$ Latimer (1932) found that, by 1932, 10\% of company pension plans were discontinued or suspended, another $10 \%$ curtailed the amount of benefits, and still others raised the amount of employee contribution (p.847). Over one hundred ERPs or 12\% were discontinued between 1928 and 1932 (Table 2) and more became inactive as most employers preferred not to ask ERP's approval for every wage cut and benefit revision (Ozanne (1967), p.146). Even the largest firms could not avoid dismissals: between 1929 and 1932, Bethlehem Steel and General Electric reduced their workforces by $50 \%$, International Harvester by $58 \%$, and Ford by $72 \%$. While the unemployment rate rose to $25 \%$, the extent of private dismissal compensation covering blue-collar workers was limited. A BLS study in 1932 found that only 18 out of 224 manufacturing establishments paid such compensation (BLS (1932))..$^{34}$

As a consequence, workers' beliefs in their employers' goodwill were considerably undermined. As Brody (1979) and Cohen (1990) emphasize, since American welfare capitalists had raised employees' expectations, their broken promises all the more generated a deep sense of disappointment if not betrayal. ${ }^{35}$ The work sharing reduced work hours so severely that workers who kept their jobs received what they called "starvation wages." Employees who initially cooperated with management to institute work sharing thus grew increasingly dissatisfied. In addition, when employers eventually resorted to layoffs, management typically used subjec-

\footnotetext{
${ }^{33}$ As mentioned above, most benefit payments were contingent on employment status, and moreover, according to typical continuous service provisions, workers who were laid-off for longer than a specified period (most commonly 6 or 12 months) lost their continuous service records and corresponding benefits (NICB (1939a), p.10; NICB (1939b), pp.11-2).

${ }^{34}$ An NICB survey found 153 concerns with active dismissal compensation plans in the early 1930s, but many of them were exclusively for white-collar employees (NICB (1937)).

${ }^{35}$ Brody (1979), p.242; Cohen (1990), pp.238-46.
} 
tive criteria combining merit, seniority, and family needs, which inflamed discontent among workers. ${ }^{36}$ Some workers were "disillusioned" by the loss of their savings especially when they had been advised by their companies to enter an unsound investment; some called their years of regular contributions to corporate programs "money thrown away"; some felt "heartbroken" when their company unilaterally eliminated the annual bonus which they had expected as part of annual compensation; some resented management for the loss of company houses when they could not maintain their payments; and some even blamed management that their layoffs were motivated by employers' desire to avoid paying principal benefits promised after certain years of service. ${ }^{37}$ A Ford worker bitterly wrote to an AFL union leader in 1933 that he had "spent a lifetime helping to create a millionaire" when the company dismissed him. ${ }^{38}$ Disturbed by reduced work, benefits, and employment, a small group of skilled workers at General Electric secretly began organizing a union in 1932 (Schatz (1983), p.63; Millis et al. (1942), p.751). In early 1933, prominent industrial relations scholar William Leiserson remarked that "this depression had undone fifteen years or so of good personnel work" and consequently "labor is going to look to legislation and not to personnel management for a solution." 39

According to the implicit contract theory, once workers perceive that their employer has breached the contract, they mistrust management and withdraw any future cooperation. One may assert, however, that since workers observed the macro economic conditions, management should have been able to convince workers that the depression was an extraordinary and unforeseen contingency. Historical evidence suggests that such renegotiation might have been difficult. Most factory workers did not possess sufficient information about their firm's financial conditions to assess whether management's breach of contract was justifiable. Employers' efforts to provide such information in a number of firms met with skepticism as workers saw no incentive for management to report truthfully. Their mistrust was reinforced partly by the fact that management often maintained corporate programs pertaining to white-collar employees while discontinuing those pertaining to blue-collar workers. ${ }^{40}$ Moreover, high rates of discontinuation

\footnotetext{
${ }^{36}$ Commons et al. (1935), p.244; Schatz (1983), p.61.

${ }^{37}$ Balderston (1933), p.265; Cohen (1990), p.240; Zahavi (1988), p.133; Fine (1969), p.26.

${ }^{38}$ V. French to W. Green (1933) quoted in Brody (1980), p.77.

${ }^{39}$ His address reprinted in Management Review 22 (1933), pp.114-5.

${ }^{40}$ For example, according to NICB (1934), only $8.5 \%$ of paid vacation plans for salaried employees were discontinued, compared to $43 \%$ for wage employees. For company-specific evidence, see Moriguchi (2002).
} 
in employee magazines, social activities, suggestion systems, and ERP meetings during the depression indicate that there was a general breakdown of labor-management communication at a critical moment that might have made renegotiation even more difficult.

\subsection{The Great Depression and Kept Promises in Japan}

Though mild by international standards, Japan's 1929 depression was the deepest recession in the nation's history, and as such, it seriously challenged managerial commitment. As industrial demand contracted by 8 percent in 1929-31, a large number of firms announced pay cuts and layoffs. In response, the number of labor disputes opposing these measures surged. As unemployment rose sharply, the Japanese government urged employers to avoid mass dismissals. ${ }^{41}$ As in the U.S., the leading proponents of corporate welfarism tried to circumvent layoffs by freezing new hiring, reducing hours, relocating workers, and creating relief work within the establishment. $^{42}$ When the reduction of the workforce became inevitable, leading employers proposed to augment the amount of retirement allowance and solicited "voluntary" retirement from among employees. Table $\mathbf{5}$ reports the amount of retirement allowances stipulated in 142 formal plans in large establishments (employing 200 or more workers) in 1932. The first column shows the average payment schedule for the retirement due to employees' personal reasons (the equivalent of a lump-sum pension) and the second column shows the average payment schedule for the retirement due to business reasons (i.e., the augmented allowance for voluntary retirement). ${ }^{43}$ The difference between the two allowances effectively is dismissal compensation, which is reported in the last column. The amount of the proposed dismissal compensation increased substantially with an employee's length of service.

Whether or not major employers adhered to their promises during the depression can be partially inferred from annual government surveys of retirement allowances covering over 5,000 private factories employing 50 or more workers (see Table 6). At the trough of the depression, the number of workers dismissed due to business reasons increased to 59,000 or 5.3 percent of total employment in the sample, and the percentage of these workers receiving any allowances

\footnotetext{
${ }^{41}$ Odaka (1984), p.203; NRUS (1959), pp.468-9; Gordon (1985), pp.145-7; Saguchi (1977), pp.211-6.

${ }^{42}$ Hazama (1978), pp.508-10; Gordon (1985), p.203.

${ }^{43}$ Zensanren (1932b); Zensanren (1932c).
} 
declined from 72 to 60 percent. ${ }^{44}$ Among those who received allowances, however, the amount per worker increased sharply from 41 days in 1929 to over 182 days in 1931, far surpassing the legal requirement of fourteen days of wages. The high level of the average payment during the depression indicates that workers with relatively long tenure were induced to retire under the augmented retirement allowance plan, as well as that a majority of the establishments with such plans did honor their promises. Company-specific evidence suggests that the system of voluntary retirement was often effective in moderating workers' discontent associated with large-scale dismissals and helped maintain the morale of the remaining employees. Many workers who were exhorted to retire saw a non-trivial sum of money provided by management as a token of goodwill. ${ }^{45}$ During the depression, a number of leading employers used ERPs to communicate managerial decisions, discuss the amount of retirement allowances, solicit employees to accept voluntary retirement, and organize relief work (Nishinarita (1988), pp.183-92).

Although it is difficult to assess the impact of the depression on corporate welfarism as a whole, a comprehensive three-volume government survey on the subject conducted in 1932 did not report any major setbacks due to the depression. ${ }^{46}$ The Japan Industrial Club conducted its second survey on welfare expenditures in 1931, at the trough of the depression, covering 118 large companies (NKK (1932)). The average welfare expenditures per employee were 41.94 yen or 12.4 percent of the annual payroll; if textile and mining industries are excluded, the figure was 10.6 percent of the payroll. Although the 1926 and 1931 surveys are not directly comparable due to sample differences, welfare expenditures as a percentage of payroll were higher in 1931 than in 1926 in every manufacturing industry except for textiles. Corresponding to the observation that major employers augmented retirement allowances, the percentage of expenditures spent on allowances (i.e., retirement, dismissal, seniority allowances) in total expenditures rose from 39 percent in 1926 to 55 percent in 1931. Taken together, the evidence suggests that leading employers maintained, if not increased, the level of their financial commitment to personnel programs despite declining corporate profits.

\footnotetext{
${ }^{44}$ The mandatory payments did not apply to concerns filing for bankruptcy.

${ }^{45}$ At a Mitsubishi Shipyard, a worker with 18 years of service said: "As I have a large family and not much saving, it is truly regrettable that I got fired now [...], but it is fortunate to receive an excessive amount of retirement allowance [...]," and similarly, a younger worker receiving retirement allowance stated that even though he was unfortunate to be dismissed he did "understand the company's situation" that necessitated such action (cited in Nishinarita (1988), p.191, in the author's translation).

${ }^{46}$ Shakaikyoku (1933); Shakaikyoku (1934). Quantitative data are reported in Table 4.
} 
Partly to mitigate the financial burden, large Japanese firms developed a system of temporary workers (rinji-ko seido) since the late 1920s. Previously, a common practice had been to promote a temporary worker to a regular worker status after a short probationary period provided his performance was satisfactory. Under the new system, the status of temporary workers was in principle fixed indefinitely. Although temporary workers were not necessarily excluded from corporate benefit plans, they were deprived of employment security as management could and did dismiss them without advance notice and retirement allowances. ${ }^{47}$ Contemporary employers emphasized that the temporary worker system served as a necessary buffer to insulate their regular "mainstay employees" from business fluctuations. ${ }^{48}$

In short, during the depression, a majority of the proponents of corporate welfarism in Japan maintained their implicit contracts, realizing that failing to do so would result in costly labor disputes and a loss of employee morale. As noted by Gordon (1985), workers' protest against the elimination of existing benefit plans gradually helped establish a belief that the benefits were part of the "just reward" that could not be withdrawn at management's will (pp.196-206). At the same time, leading employers modified existing practices and developed institutional arrangements (i.e., voluntary retirement and temporary-worker systems) that would reduce the cost of long-term commitment.

\section{Endogenous Transformation of the "Rules of the Game"}

The divergent managerial responses to the depression in the U.S. and Japan were reinforced by concurrent government legislations that eventually changed "the rules of the game" for private players. Although the intents of the government interventions in the two countries were similar, I argue that the nature of labor laws was endogenously determined. In the early 1930s, the two countries were at similar political crossroads, introducing collective bargaining and social welfare legislation prompted by depression crises. However, reflecting the change in the relative power of constituencies and the dominant beliefs in the societies, legislative outcomes diverged between the two countries. In the U.S., the New Deal legal framework brought an end to corporate

\footnotetext{
${ }^{47}$ Temporary workers were hired under a renewable fixed-term contract and received lower wages compared to regular workers even though they performed similar tasks. See Nishinarita (1988), p.52; Sumiya (1966), p.134; Odaka (1984), p.213.

${ }^{48}$ NRUS (1964), pp.123-48; Hyōdō (1971), p.432; Hazama (1978), p.498.
} 
welfarism characterized by implicit contracts in most establishments, while Japanese labor laws legitimized these practices.

\subsection{The New Deal Labor Laws and the Rise of Explicit Contracts in the U.S.}

In the 1932 election, the Democrats won both the presidency and a majority in Congress. The Roosevelt administration of 1932 critically relied on political support from progressive Republicans who were disillusioned by Hoover. ${ }^{49}$ Reflecting his constituencies, Roosevelt's first economic measure, the National Industry Recovery Act (NIRA) of 1933, was primarily procorporate legislation that granted business a long-sought antitrust exemption coupled with one labor provision, Section $7(\mathrm{a}) .{ }^{50}$ Labor leaders declared Section 7(a) the first congressional sanction of trade unions in U.S. history, while business leaders claimed that it recognized ERPs as an equally legitimate collective bargaining unit (Bernstein (1950), p.38; Bernstein (1969), p.41). The NIRA thus set off a fierce rivalry between trade unions and ERPs. The number of labor disputes rose and union membership started to expand after 1933, while several hundred ERPs were created anew under employers' initiatives in 1933-35 (NICB (1933); Troy (1965)). By the time the NIRA was declared unconstitutional, it had generated two largely unintended outcomes: the failure to achieve economic recovery under business initiatives and the rise of organized labor. ${ }^{51}$ The former led Roosevelt to abandon voluntarist corporatism inherited from Hoover, while the latter enabled him to form a new political coalition with organized labor. As a result, after the midterm election of 1934 in which the Democrats further gained, there was an emerging rift between business leaders and the administration (Finegold \& Skocpol (1995), pp.136-8).

Against this political backdrop, Congress passed the National Labor Relations Act (Wagner Act) and the Social Security Act in 1935. The Wagner Act was more than the reinstatement of the NIRA Section 7(a): it prohibited employers from engaging in "unfair labor practices" explicitly outlawing ERPs or any other employer-sponsored labor organizations, and established

\footnotetext{
${ }^{49}$ Finegold \& Skocpol (1995), pp.45-7.

${ }^{50}$ Section 7 (a) recognized the right of employees to organize and bargain collectively through representatives of their own choosing and prohibited employers from interfering with that right.

${ }^{51}$ In May 1935, the Supreme Court declared the NIRA unconstitutional as it granted undue power to the President with vaguely defined objectives in Schechter Poultry Corp. v. United States (295 U.S. 495).
} 
the National Labor Relations Board (NLRB) granting exclusive judicial power in industrial relations. The Social Security Act introduced compulsory state unemployment compensation and federal old-age pensions financed by payroll taxes. Business leaders immediately launched a campaign against the two Acts, emphasizing employers' voluntary efforts to improve employees' welfare, and filed legal challenges to their constitutionality. ${ }^{52}$ In the meantime, the passage of the Wagner Act further stimulated the union movement: most notably, the newly-established Committee of Industrial Organization (CIO) promoted industrial unionism in mass production industries.

In 1936, Roosevelt won his second presidential election, securing labor's support but further alienating business. ${ }^{53}$ In the same year, endorsed by Congress, the La Follette Committee began an investigation of employers' infringements of civil liberties. Collaborating with the NLRB, the Committee discovered that numerous American firms, including welfare capitalists such as General Motors and U.S. Steel, had engaged in unlawful antiunion practices during the NIRA period (Auerbach (1966), p.85). ${ }^{54}$ Since the La Follette congressional hearings generated wide publicity, even though the nature and extent of the anti-labor practices varied substantially across firms, the reputation of "progressive business" fell apart, making American private welfare capitalism a synonym for antiunionism. Consequently, the investigation served to justify the Wagner Act's sweeping prohibition of unfair labor practices and mitigated the public sentiment against radicalizing labor movement. Even though 4,720 strikes broke out in 1937 mobilizing two million workers, as a clear departure from precedent, federal and state governments rarely intervened against unions despite the unions' obvious militancy (Goldstein (1978), pp.228-9). In its watershed decision in 1937, the Supreme Court narrowly upheld the Wagner and Social Security Acts.

The new legal framework had a far-reaching impact on corporate welfarism. Its first implication was the demise of ERPs. Between 1935 and 1941, the NLRB found 1,200 cases of company-dominated labor organizations in violation of the Wagner Act and ordered their dises-

\footnotetext{
${ }^{52}$ Jacoby (1985), p.241; NICB (1936).

${ }^{53}$ Andersen (1979), pp.92-120; Finegold \& Skocpol (1995), pp.136-8.

${ }^{54}$ According to the Committee's findings, the most common antiunion practices were labor espionage, strikebreaking, and munitioning; for example, the Committee found that, between 1933 and 1936, some 2,500 firms hired 4,000 spies to infiltrate unions and that some firms spent a considerable sum of money on machine guns, pistols, and other weapons to arm their strikebreakers and private police forces (Committee on Education and Labor (1937a); Committee on Education and Labor (1937b)).
} 
tablishment. The newly created ERPs under the NIRA were particularly prone to this allegation. After the court's validation of the Wagner Act, however, the employers who had long-standing ERPs, such as Bethlehem Steel, General Electric, and International Harvester, also had to dissolve their ERPs in compliance with the law. Although many of those ERPs were reconstituted as so-called independent local unions, a majority of them lost against CIO- or AFL-affiliated unions in subsequent unionization drives. ${ }^{55}$ By 1941, over 8 million workers had joined trade unions, whereas the membership of ERPs (or independent local unions) declined to less than half a million (Table 2). Major proponents of corporate welfarism, including Bethlehem Steel, General Electric, General Motors, Goodyear, International Harvester, and U.S. Steel, were organized by industrial unions between 1936 and 1941 .

The second implication of the New Deal labor laws was the rise of explicit employment contracts in major establishments. As most employers fought aggressively against trade unions, the process of union recognition were often confrontational and violent. As a consequence, adversarial labor-management relations took root in most unionized establishments (Millis (1942); Bernstein (1969)). According to the implicit contract theory, in the absence of mutual trust, management and labor cannot sustain the implicit contract equilibrium. Instead of reverting to spot contracting, however, they may institute a better contractual arrangement based on thirdparty enforcement. Historical evidence suggests that adversarial labor-management relations led to the development of explicit and elaborate union contracts. During the collective bargaining process, leading employers recognized the merit of defining explicit and detailed rules ex ante in forestalling union grievances and protecting managerial prerogatives. Unions also preferred establishing contractual rights based on objective and verifiable rules in minimizing managerial discretion and demanded third-party arbitration in case of disagreements. ${ }^{56}$ Accordingly, management and labor in unionized establishments began to develop explicit contracts, characterized by detailed job classifications and seniority rules, foreshadowing the "workplace contractualism" of the postwar U.S. industrial relations system (Slichter (1941); Brody (1993)).

The third implication of the new legal framework was the decline of discretionary corpo-

\footnotetext{
${ }^{55}$ Troy (1965); Jacoby (2000).

${ }^{56}$ For example, major employers introduced formal methods of job analysis and evaluation to determine wage rates, while major unions demanded the strict seniority principle in layoffs and promotions and the usage of third-party arbitration in the grievance procedure (Jacoby (1985), pp.250-2; Brody (1993), p.180).
} 
rate benefits pertaining to blue-collar workers in unionized plants. Since the Social Security Act provided compulsory pensions and unemployment benefits on a uniform basis, it diminished employers' returns from providing benefits to induce the acquisition of desirable human capital. ${ }^{57}$ With the introduction of the federal pensions, a number of welfare capitalist firms reduced or discontinued their corporate pension plans for wage earners. Furthermore, most unions opposed any discretionary benefits unilaterally granted by employers and demanded to make the payment of such benefits contractual obligations for the firm. In response, many major employers eliminated extra compensation plans pertaining to blue-collar workers (e.g., employee stockownership, profit sharing, and bonus plans), or incorporating some plans into union contracts as explicit benefits based on seniority rights (e.g., paid vacations, group insurance). ${ }^{58}$

In summary, the New Deal labor laws imposed binding constraints on corporate welfarism based on implicit contracts and internal enforcement mechanisms. Toward the early 1940s, employment relations in major unionized U.S. establishments were increasingly characterized by explicit contracts based on third-party enforcement.

\subsection{Prewar Labor Laws and the Endorsement of Corporate Welfarism in Japan}

Although Japan was under the oligarchic regime before 1918, the elective Lower Diet gained political power vis-à-vis the peerage Upper Diet in the 1920s, giving rise to a brief period of parliamentary democracy. ${ }^{59}$ In the Lower Diet, conservative and rural-based Seiyūkai and progressive and urban-based Minseitō became two major political parties, alternately forming a cabinet between 1924 and 1931 (Kawato (1992), pp.176-9). Drawing support from the working class, Minseitō won a majority in the Lower Diet for the first time in the 1930 election (Garon (1988), pp.164-5). Prompted by the depression crisis, the Minseitō cabinet introduced three pieces of legislation to the Diet in 1930-32 that were comparable to New Deal legislation in the U.S. during the same period: an economic recovery bill that would authorize business to

\footnotetext{
${ }^{57}$ As Berkowitz \& McQaid (1980) and Tone (1997) emphasize, the Social Security Act incorporated aspects of corporate welfare practices. As shown in the following section, however, the impact of corporate welfarism on state welfare policies in the U.S. was far smaller than in Japan.

${ }^{58}$ Eventually the court decision in 1949 brought the terms of non-wage benefits within the scope of collective bargaining, upon which employers lost their discretion (Munts (1967); Harris (1982)).

${ }^{59}$ The Upper Diet possessed veto power, but by the 1920 s, it was rare for peers to overrule any bills that received wide public support, as the government could and did threaten the Upper Diet with peerage reform.
} 
form cartels, a trade union bill that would recognize workers' collective bargaining rights, and a national unemployment insurance bill (Rōdōshō (1961), p.441).

Japanese employers immediately formed a united front against the trade union bill. Testifying in the Diet, business leaders contended that the legal recognition of unions in the midst of the depression would only intensify labor disputes and create grave consequences for industrial development. Like American employers, they also claimed that such law would endanger plant-level ERPs that had "greatly contributed" to the establishment of mutual trust between management and labor (Rōdōshō (1961), p.434). Government officials countered that corporate welfarism rested entirely on the "whims of capitalists," offering no solution to the mounting problem of unemployment and labor unrest (Garon (1988), p.173). The Lower Diet passed the union bill in 1931 after overcoming substantial opposition, and the union movement surged in the anticipation of the passage of the bill. In the Upper Diet, however, the bill was stalled indefinitely by a coalition of leading industrialists and conservative peers. ${ }^{60}$

In contrast to the U.S. outcome, Japanese business narrowly blocked union legislation during the depression. As leading Japanese employers kept their reputation of benevolent management better than their American counterparts, they were able to draw on the goodwill of their employees. Organized labor in Japan, by contrast, was deemed "radical" by the public and failed to gain wide support from workers, especially in large establishments. Importantly, the defeat of the union bill in 1931 was not caused by military intervention. Political power effectively fell into the hands of the military in the following year; but even then, government policies toward unions changed little between 1932 and 1937 and union membership continued to increase until 1936. Major establishments adopting corporate welfarism, however, remained nonunion. Even before the government repression of trade unions starting in 1937, the number of workers covered by ERPs or similar employee organizations far exceeded union membership in Japan. ${ }^{61}$

In 1932, government officials began drafting an unemployment insurance bill, which business leaders opposed, asserting that in the presence of corporate retirement allowance practices there was no need for state intervention (Saguchi (1977), pp.222-3). During the prolonged legislative process, the unemployment insurance bill was transformed into the Retirement Allowance Fund

\footnotetext{
${ }^{60}$ NRUS (1959), VI-1; Garon (1988), pp.1777-184; Rōdōshō (1961), pp.439-58.

${ }^{61}$ Gordon (1985), pp.251-3; Taira (1970), p.146; Garon (1988), pp.157-70.
} 
Law of 1936, which obligated every firm with 50 or more employees to set up a retirement allowance fund for each employee. Notably, affirming prevailing corporate practices, the law established the minimum amount of the retirement allowance contingent on an employee's length of service and the reason for separation (Rōdōshō (1961), pp.310-23). Employers further won a provision that allowed firms with retirement funds of "sufficient scope" to continue operating their original plans with little modification (NRUS (1964), pp.280-328). Gordon (1987) calls the law "an ingenious variant of unemployment compensation" as it did not simply rely on managerial benevolence, but explicitly linked a worker's entitlement to unemployment benefits to "the quality of his service to a particular employer" (pp.268-9). Thus, in contrast to the Social Security Act in the U.S., unemployment insurance in Japan legitimized and incorporated corporate welfarism, while leaving substantial discretion to employers. By the late 1930s, regular blue-collar workers in large establishments saw corporate benefits as part of their compensation, while business leaders described the provision of employment security and non-wage benefits to these employees as their moral and social responsibility (Morita (1958), pp.417-8).

In summary, the Japanese government continued to support corporate welfarism and ERPs with the expectation that they would bring about industrial peace, social stability, and high productivity. Consequently, labor laws in the U.S. and Japan evolved in different directions during the 1930s, reinforcing the diverging institutional paths.

\section{Concluding Remarks}

This paper documents parallel institutional trajectories in the U.S. and Japan in the 1920s and the process of bifurcation triggered by the Great Depression. By the early 1940s, employment relations pertaining to blue-collar workers in the two countries began to diverge towards two distinct equilibria. It took, however, two more decades for the establishment of modern industrial relations systems (Moriguchi (2000)). Labor regulations during WWII propelled the bifurcation process, as the respective governments tended to design their measures based on prevailing corporate practices, as well as the selective compliance by employers and workers undermined the regulations that were incompatible with prevailing practices. Despite a deep recession and labor law reforms during the U.S. Occupation (1945-52), Japan continued down the same path due largely to accumulated institutional capital. By 1960, explicit and elaborate employment 
contracts based on industrial unions and third-party enforcement were institutionalized in large U.S. industrial firms, while implicit and discretionary contracts based on enterprise unions and internal enforcement mechanisms emerged in their Japanese counterparts.

The comparative analysis indicates the following counterfactual for the U.S. Had the economy begun to recover by 1931, American welfare capitalists could have maintained most of their implicit promises during the depression. If the public support for private welfarism as a result had been stronger, Congress might not have been able to pass the sweeping ban on unfair labor practices included in the Wagner Act. And if so, a much larger fraction of ERPs in the U.S. might have won against trade unions and have supported corporate welfare practices. In other words, the Great Depression was not only sufficient but most likely necessary to induce the decline of corporate welfarism characterized by implicit and discretionary contracts. Thus, I argue that the replacement of American private welfare capitalism by trade unionism and state welfarism was not inevitable, but rather the outcome of a delicate historical contingency.

The paper hence highlights the dynamic process of equilibrium selection and path-dependence of the U.S. institutional trajectory. There were, however, important differences between the two countries prior to the depression that were counter to the premise of the natural experiment. I consider three alternative hypotheses to the historical contingency thesis developed in this paper. First, cultural determinism argues that the individualism and cultural heterogeneity in the U.S. were sufficient in precluding implicit contractual relations. Second, technological determinism argues that the scientific management and mass production technology developed in the U.S. resulted in the rise of explicit contracts. Third, political determinism argues that the imperial government in Japan suppressed organized labor more so than the democratic government in the U.S., ensuring the dominance of ERPs over trade unions. Although each of the three factors clearly played an important role, I argue that none of them alone would have dictated the observed outcomes. Historical evidence indicates the transformation of workplace culture (e.g., work ethics, loyalty, trust) in the respective countries in response to economic incentives and institutional environment, which was not necessarily predetermined by the national culture (Gordon (1985)). The technological determinism overemphasizes the link between Taylorism and workplace contractualism: during the 1920s, American management often regarded scientific management and corporate welfarism as complementary practices to attain higher 
productivity (Nelson \& Campbell (1972)), and postwar Japanese establishments combined both methods in developing a system of flexible mass production (Tsutsui (1998)).

Regarding political determinism, it is important to note that even in democratic America, the passage of the Wagner Act was by no means guaranteed but depended on historical conditions. To assess the role of the Japanese government, I propose the following thought experiment. Suppose that the depression in Japan were as severe as in the U.S. With a much higher fraction of employers abandoning their corporate welfare practices, business might have lost credibility and failed to block the 1931 union law, which, in turn, might have stimulated labor movement in large Japanese establishments. It is correct to argue that the right-wing government would have eventually crashed unions regardless of the passage of the union law. However, had Japanese trade unions taken stronger roots in the prewar period, the outcome of the postwar union movement under a democratic regime might have turned out differently. That is, in the fiercely contested representation elections in the late 1940s, industrial unions might have won over ERPs in major companies, promoting explicit-contractual relations. As powerful as it was, the military intervention might have not been sufficient to ensure the the prevalence of corporate welfarism in Japan.

Finally, the paper documents that the institutional change induced by the Great Depression in the U.S. became less "reversible" as it was accompanied by the endogenous formation of complementary institutions, such as collective bargaining organizations, legal enforcement agency, and state social welfare programs. The paper thus identifies a mechanism in which a temporary economic shock could generate a lasting impact on long-run institutional development. By combining a game-theoretic framework and an empirical historical investigation, the paper contributes to better understanding the dynamics of institutional change. 


\section{References}

Allen, H. (1943), The House of Goodyear: A Story of Rubber and Modern Business, Corday \& Gross Company.

Alston, L. \& Ferrie, J. (1999), Southern Paternalism and the American Welfare State: Economic, Politics, and Institutions in the South, 1865-1965, Cambridge University Press.

AMA (1925), Cost-findings for Personnel Activities, American Management Association.

Andersen, K. (1979), The Creation of a Democratic Majority, 1928-1936, University of Chicago Press.

Auerbach, J. (1966), Labor and Liberty: The La Follette Committee and the New Deal, Bobbs-Merrill.

Baker, G., Gibbons, R. \& Murphy, K. J. (1994), 'Subjective performance measures in optimal incentive contracts', Quarterly Journal of Economics 109, 1125-1156.

Balderston, C. (1933), 'Recent trends in personnel management', Management Review 22, 259-266.

Berkowitz, E. \& McQaid, K. (1980), Creating the Welfare State, Praeger.

Bernstein, I. (1950), The New Deal Collective Bargaining Policy, University of California Press.

Bernstein, I. (1960), The Lean Years: A History of the American Worker, 1920-1933, Houghton Mifflin; Boston.

Bernstein, I. (1969), The Turbulent Years: A History of the American Worker, 1933-1941, Houghton Mifflin; Boston.

Berridge, W. (1929), 'Labor turnover in American factories', Monthly Labor Review 29, 62-65.

BLS (1913), 'Bulletin No.123: Employers' Welfare Work'.

BLS (1917), 'Bulletin No.208: Profit Sharing in the United States'.

BLS (1919), 'Bulletin No.250: Welfare Work for Employees in Industrial Establishments in the United States'.

BLS (1927), 'Vacation with pay for industrial workers', Monthly Labor Review.

BLS (1928), ' Bulletin No.458: Health and Recreation Activities in Industrial Establishments, 1926'.

BLS (1932), 'Hiring and separation methods in American factories', Monthly Labor Review 35, 1005-1017.

Brandes, S. (1970), American Welfare Capitalism, 1880-1940, University of Chicago Press.

Brody, D. (1980), Workers in Industrial America, Oxford University Press.

Brody, D. (1993), Workplace contractualism in comparative perspective, in Lichtenstein \& Harris, eds, 'Industrial Democracy in America', Cambridge University Press.

Chase, S. (1947), A Generation of Industrial Peace: Thirty Years of Labor Relations at Standard Oil Company, Standard Oil Company.

Chūma, H. (1987), 'Nihonteki koyō kankō no keizai gōrisei saikentō (Economic rationality of Japanese employment practices revisited)', Keizai Kenkyū 38, 307-320.

Cohen, L. (1990), Making A New Deal: Industrial Workers in Chicago, 1919-1939, Cambridge University Press.

Committee on Education and Labor (1937a), Industrial Espionage, Report No.46, Part 3: 75th Congress, 2nd Session.

Committee on Education and Labor (1937b), Strikebreaking Services, Report No.6, Part 1: 76th Congress, 1st Session. 
Commons, J. R., Lescohier, D. \& Brandeis, E., eds (1935), History of Labor in the United States, 18961932, MacMillan Company; New York.

Dunn, R. (1927), The Americanization of Labor: The Employers' Offensive Against the Trade Unions, International Publishers; New York.

Epstein, A. (1926), The Problem of Old Age Pension in Industry, Pennsylvania Old Age Pension Commission.

Fairris, D. (1997), Shopfloor Matters: Labor-Management Relations in Twentieth-Century American Manufacturing, Routledge.

Fausold, M. (1985), The Presidency of Herbert C. Hoover, University of Kansas Press.

Fine, S. (1969), Sit-down: The General Motors Strike of 1936-1937, University of Michigan Press.

Finegold, K. \& Skocpol, T. (1995), State and Party in America's New Deal, University of Wisconsin Press.

Fishback, P. (1992), 'The economics of company housing: Historical perspectives from the coal fields', Journal of Law, Economics and Organization 8, 346-365.

Fishback, P. \& Kantor, S. (1995), 'Did workers pay for the passage of workers' compensation laws?', Quarterly Journal of Economics 110, 713-742.

Friedman, M. \& Schwartz, A. (1963), A Monetary History of the United States, 1867-1960, Princeton University Press.

Garon, S. (1988), The State and Labor in Modern Japan, University of California Press.

Goldstein, R. (1978), Political Repression in Modern America: From 1870 to the Present, Schenkman Publishing Company.

Gordon, A. (1985), The Evolution of Labor Relations in Japan: Heavy industry 1853-1955, Harvard University Press.

Gray, E. \& Gullett, R. (1973), 'Employee representation at Standard Oil Company of New Jersey: A case study'. Occasional Paper Number 11; College of Business Administration, Louisiana State University.

Greif, A. (1993), 'Contract enforceability and economic institutions in early trade: The Maghribi traders' coalition', American Economic Review 83, 525-548.

Greif, A., Milgrom, P. \& Weingast, B. (1994), 'Coordination, commitment, and enforcement: The case of the merchant guild', Journal of Political Economy 102(4), 745-776.

Harris, H. (1982), The Right to Manage: Industrial Relations Policies of American Business in the 1940s, University of Wisconsin Press.

Hawley, E. (1979), The Great War and the Search for a Modern Order: A History of the American People and their Institutions, St. Martin's Press.

Hazama, H. (1978), Nihon Rōmu Kanri-shi Kenkyū (Historical Studies of Japanese Labor Management), Ochonomizu Shobō.

Hicks, C. (1941), My Life in Industrial Relations: Fifty Year in the Growth of a Profession, Harper \& Brothers.

Houser, J. D. (1927), What The Employer Thinks: Executives' Attitudes Toward Employees, Harvard University Press.

Hunter, H. (1982), 'The role of business liquidity during the Great Depression and afterwards: Difference between large and small firms', Journal of Economic History 42, 883-902. 
Hyōdō, T. (1971), Nihon ni okeru Rōshi Kankei no Tenkai (The Evolution of Labor-Capital Relations in Japan), Tōkyō Daigaku Shuppankai.

Jacoby, S. (1985), Employing Bureaucracy: Managers, Unions, and the Transformation of Work in American Industry, 1900-1945, Columbia University Press.

Jacoby, S. (1993), 'Pacific ties: Industrial relations and employment systems in Japan and the United States since 1960', in Lichtenstein \& Harris, eds, 'Industrial Democracy in America', Cambridge University Press.

Jacoby, S. (2000), 'A road not taken: Independent local unions in the United States since 1935', in B. Kaufman \& D. Taras, eds, 'Nonunion Employee Representation', M. E. Sharpe.

Kanemoto, Y. \& MacLeod, B. (1989), 'Optimal labor contract with non-contractible human capital', Journal of the Japanese and International Economies 3, 385-402.

Kaufman, B. \& Taras, D., eds (2000), Nonunion Employee Representation: History, Contemporary Practice, and Policy, M. E. Sharpe.

Kawato, S. (1992), Nihon no Seitō Seiji (Party Politics in Japan), Tōkyō Daigaku Shuppankai.

Komatsu, R. (1971), Kigyō-betsu Kumiai no Seisei (The Origins of Enterprise Unions), Ochanomizu Shobō.

Kyōchōkai (1920), Beikoku Shokōjō ni okeru Fkuri Zōshin Shisetsu (Welfare Facilities in American Factories), Kyōchōkai.

Kyōchōkai (1921), Beikoku Kōjō Hiyōsha Fkuri Zōshin Jigyō (Welfare Activities for American Factory Employees), Kyōchōkai.

Kyōchōkai (1924), Hompō Sangyō Fukuri Shisetsu Gaiyō (An Overview of Industrial Welfare Facilities in Japan), Kyōchōkai.

Kyōchōkai (1929), Saikin no Shakai Undō (Recent Social Movements), Kyōchōkai.

Kyōchōkai (1932), Taishoku Teate Seido no Genjō (The Current Conditions of Retirement Allowance Plans), Kyōchōkai.

Latimer, M. (1932), Industrial Pension Systems in the United States and Canada, Industrial Relations Conselors.

Lazear, E. (1979), 'Why is there mondatory retirement?', Journal of Political Economy 87, 1261-1284.

MacLeod, B. \& Malcomson, J. (1989), 'Implicit contracts, incentive compatibility, and involuntary unemployment', Econometrica 57(2), 447-480.

Millis, H., ed. (1942), How Collective Bargaining Works: A Survey of Experience in Leading American Industries, The Twentieth Century Fund.

Mimura, K. (1930), 'Sumitomo kōjō kyōgikai jūnen no sokuseki (Ten years of Sumitomo factory councils)', Shakai Seisaku Jihō.

Mitsubishi Gōshi (1921), Beikoku ni okeru Kōjō Iinkai (Factory Councils in the U.S.), Mitsubishi Gōshi Research Division.

Moriguchi, C. (2000), The evolution of employment relations in U.S. and Japanese manufacturing firms, 1900-1960: A comparative historical and institutional analysis, NBER Working Paper No.7939.

Moriguchi, C. (2001), Implicit contracts, the Great Depression, and institutional change: A comparative study of U.S. and Japanese manufacturing firms, 1910-1940, mimeography, Department of Economics, Northwestern University. 
Moriguchi, C. (2002), Did American welfare capitalists breach their implicit contracts? A preliminary study of company-level data, 1920-1940, mimeography, Department of Economics, Northwestern University.

Morita, Y. (1958), Nihon Keieisha Dantai Hatten-shi (Historical Development of Employers'Associations in Japan), Nikkan Rōdō Tsūshinsha.

Munts, R. (1967), Bargaining for Health: Labor Unions, Health Insurance, and Medical Care, University of Wisconsin Press.

Nelson, D. (1975), Managers and Workers: Origins of the Twentieth-Century Factory System in the U.S., 1880-1920, University of Wisconsin Press.

Nelson, D. (1982), 'The company union movement, 1900-1937: A reexamination', Business History Review 56, 335-357.

Nelson, D. \& Campbell, S. (1972), 'Taylorism versus welfare work in American industry: H.L. Gantt and the Bancrofts', Business History Reviews 46, 1-16.

Nelson-Rowe, S. (1991), 'Corporation schooling and the labor market at General Electric', History of Education Quarterly 31, 27-46.

NICB (1925a), Employee Magazines in the United States, National Industrial Conference Board.

NICB (1925b), Industrial Pensions in the United States, National Industrial Conference Board.

NICB (1925c), Special Report No.32: The Growth of Works Councils in the United States, National Industrial Conference Board.

NICB (1928a), The Economics Status of the Wage Earners in New York and Other States, National Industrial Conference Board.

NICB (1928b), Employee Stock Purchase Plans in the United States, National Industrial Conference Board.

NICB (1929), Industrial Relations Programs in Small Plants, National Industrial Conference Board.

NICB (1930), Lay-Off and Its Prevention, National Industrial Conference Board.

NICB (1931), Industrial Relations: Policies and Programs, National Industrial Conference Board.

NICB (1933), Individual and Collective Bargaining under the N.I.R.A., National Industrial Conference Board.

NICB (1934), Effect of the Depression on Industrial Relations Programs, National Industrial Conference Board.

NICB (1936), What Employers Are Doing for Employees: A Survey of Voluntary Activities for Improvement of Working Conditions in American Business Concerns, National Industrial Conference Board.

NICB (1937), Studies in Personnel Policies No.1: Dismissal Compensation, National Industrial Conference Board.

NICB (1939a), Studies in Personnel Policies No.10: Health Insurance Plans: B. Group Health Insurance Plans, National Industrial Conference Board.

NICB (1939b), Studies in Personnel Policy No.13: Developments in Company Vacation Plans, National Industrial Conference Board.

Nishinarita, Y. (1988), Kindai Nihon Rōshi Kankei-shi no Kenkyū (A Historical Study of the Modern Japanese Labor-Capital Relations), Tōkyō Daigaku Shuppankai. 
NKK (1928), Fukuri Shisetsu-hi ni kansuru Chōsa I (A Survey on Welfare Expenditures I), Nihon Kōgyō Kurabu.

NKK (1932), Fukuri Shisetsu-hi ni kansuru Chōsa II (A Survey on Welfare Expenditures II), Nihon Kōgyō Kurabu.

NRUS (1959), Nihon Rōdō Undō Shiryō (Historical Data of the Labor Movement in Japan), vol.X: Statistics, Nihon Rōdō Undō Shiryō Kankō Iinkai.

NRUS (1964), Nihon Rōdō Und̄̄ Shiryō (Historical Data of the Labor Movement in Japan), vol.VII, Nihon Rōdō Undō Shiryō Kankō Iinkai.

Odaka, K. (1984), Rōdō Shijō Bunseki (Labor Market Analysis), Iwanami Shoten.

Owen, L. (1995a), 'Worker turnover in the 1920s: The role of changing employment policies', Industrial and Corporate Change 4, 499-530.

Owen, L. (1995b), 'Worker turnover in the 1920s: What labor-supply arguments don't tell us', Journal of Economic History 55, 822-841.

Ozanne, R. (1967), A Century of Labor-Management Relations at McCormick and International Harvester, University of Wisconsin Press.

Piore, M. \& Sabel, C. (1984), The Second Industrial Divide, Basic Books; New York.

Prendergast, C. (1993), 'The role of promotion in inducing specific human capital acquisition', Quarterly Journal of Economics 108, 523-534.

Rōdōshō (1961), Rōdō Gyōsei-shi (History of Labor Administration), vol.I, Rōdō Hōrei Kyōkai.

Rumm, J. (1989), Mutual Interests: Managers and Workers at the Du Pont Company, 1802-1915, PhD thesis, University of Delaware.

Saguchi, T. (1977), Nihon Shakai Hoken Seido Hatten-shi (Historical Development of the Social Insurance System in Japan), Keisō Shobō.

Schacht, J. (1975), 'Toward industrial unionism: Bell telephone workers and company unions, 1919-1937', Labor History 16, 5-36.

Shakaikyoku (1933), Kōjō Kōzan no Fukuri Shisetsu Chōsa I $\mathcal{G}$ II (A Survey on Welfare Facilities in Industrial Establishments I $\mathcal{G}$ II), Naimushō Shakaikyoku (Home Ministry, Social Bureau).

Shakaikyoku (1934), Kōjō Kōzan no Fukuri Shisetsu Chōsa III (A Survey on Welfare Facilities in Industrial Establishments III), Naimushō Shakaikyoku.

Shakaikyoku (1936), Taishoku Tsumitatekin oyobi Taishoku Teate Hōan Yōkō oyobi Shiryō (Summary and Documents of the Retirement Allowance Fund Law), Naimushō Shakaikyoku.

Shapiro, C. \& Stiglitz, J. (1984), 'Equilibrium unemployment as a worker discipline device', American Economic Review 74, 433-444.

Shōwa Dōjin-kai, ed. (1960), Wagakuni Chingin Kōzō no Shiteki Kōsatsu (Historical Reflections on the Japanese Wage Structure), Shiseidō.

Slichter, S. (1929), 'The current labor policies of American industries', Quarterly Journal of Economics 43, 393-435.

Slichter, S. (1941), Union Policies and Industrial Management, Brookings Institution.

Sumiya, M. (1966), Nihon Rōdō Undō-shi (History of Japanese Labor Movement), Yūshindō.

Sundstrom, W. (1986), Studies in the Evolution of the Employment Relationship in American Manufacturing, 1880-1930, PhD thesis, Department of Economics, Stanford University. 
Taira, K. (1970), Economic Development and the Labor Market in Japan, Columbia University Press.

Tone, A. (1997), The Business of Benevolence: Industrial Paternalism in Progressive America, Cornell University Press.

Troy, L. (1965), Trade Union Membership, 1897-1962, Technical report, National Bureau of Economic Research, Occasional Paper 92.

Tsutsui, W. (1998), Manufacturing Ideology: Scientific Management in Twentieth-century Japan, University Press.

Whatley, W. \& Sedo, S. (1997), The origins of modern labor markets: New evidence from company personnel records, mimeo., Department of Economics, University of Michigan.

Young, C. \& Tuttle, R. (1969), The Years 1919-1969: A History of General Motors Institute, General Motors Institute.

Zahavi, G. (1988), Workers, Managers, and Welfare Capitalism: The Shoeworkers and Tanners of Endicott Johnson, 1890-1950, University of Illinois Press.

Zensanren (1932a), Beikoku Koshu no Rōshi Kankeikan to sono Jittai (American Employers' Views of Labor-Capital Relatons and their Conditions), Zenkoku Sangyō Dantai Rengō.

Zensanren (1932b), Wagakuni ni okeru Kaiko Teate Seido no Genjō (The Current Conditions of Dismissal Allowance Plans in Japan), Zenkoku Sangyō Dantai Rengō.

Zensanren (1932c), Wagakuni ni okeru Rōmusha Taishoku Teate Seido no Genjōo (The Current Conditions of Retirement Allowance Plans in Japan), Zenkoku Sangyō Dantai Rengō. 
Figure 1. Annual Turnover Rates in Manufacturing Establishments in the U.S. and Japan, 1910-1960

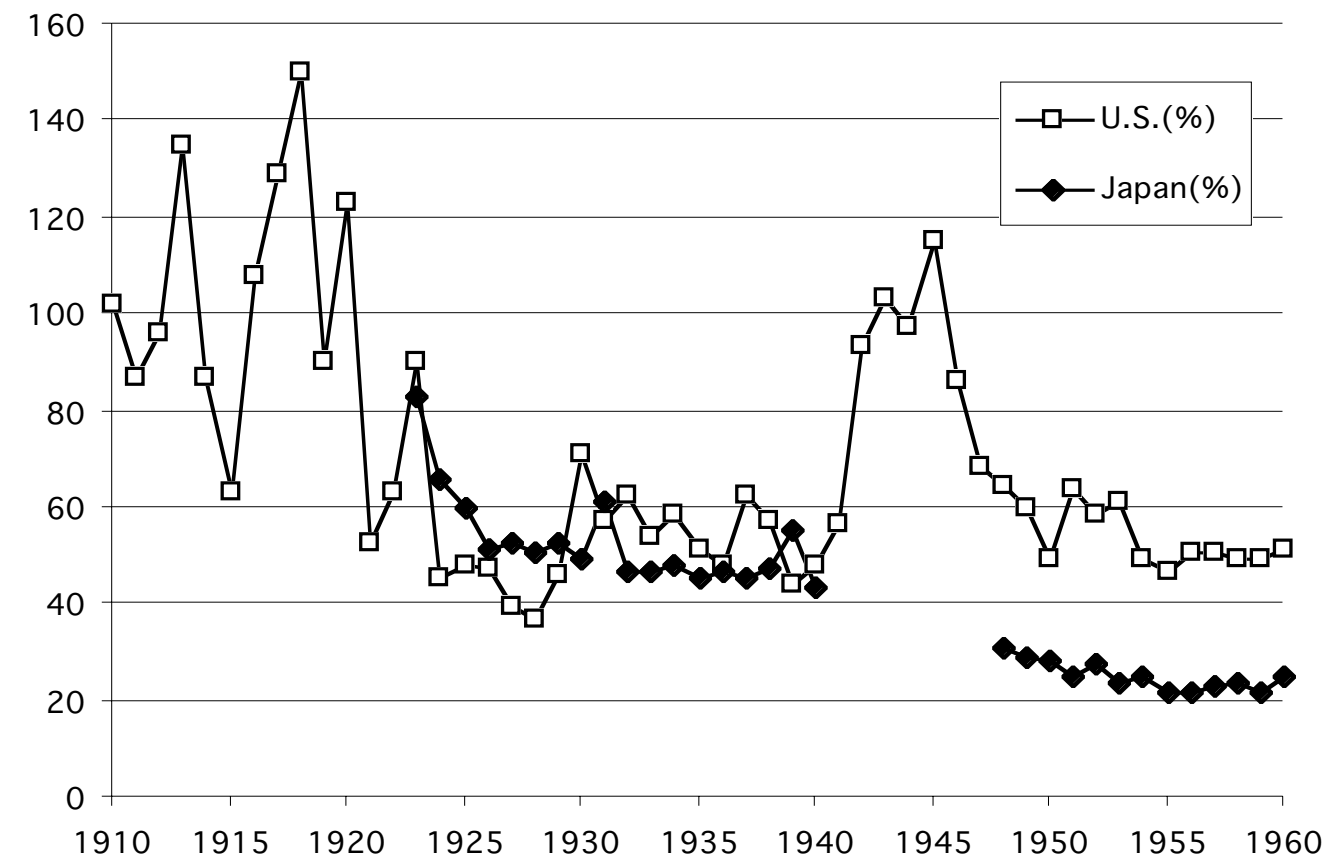

U.S. Source: (I) 1910-18: Brissenden and Frankel (1920), Monthly Labor Review 10, pp.1342-62; (II) 1919-29: Berridge (1929), Monthly Labor Review 29, pp.64-5; (III) 1930-70: U.S. Department of Labor, Employment, Hours, and Earnings.

1) Labor turnover is the sum of voluntary quits, layoffs, and discharges.

2) An annual turnover rate is the annual average of monthly turnover rates; a monthly turnover rate is the number of workers separated from a given establishment within a month divided by the average size of work force during that month.

3 ) In (I), turnover rates per 10,000 labor hours were reported. Annual turnover rates were computed assuming that one worker worked 30,000 labor hours per year. The survey covered manufacturing and non-manufacturing (public utilities and mercantile) establishments.

4) In (II), the unweighted median of the turnover rates for all sample firms was reported each year. The survey covered 350 manufacturing establishments employing 700,000 workers in 1929.

5) In (III), the weighted average of the turnover rates for all firms in the sample was reported each year. The survey covered 38,000 manufacturing establishments employing 104,000,000 workers in 1970 .

6) Before 1943, the data were production workers only; after 1943, the data covered all employees.

Japanese Source: (I) 1923-36: Nihon Rodo Undo Shiryo (1959), II-60; (II) 1937-40: IOSR (1965), Taiheiyo Sensoka no Rodo Jotai (The Condition of Workers during the Pacific War), p.41; (III)

1948-75: Japanese Ministry of Labor, Monthly Labor Survey.

1) No turnover data are available before 1923 and between 1941-47.

2) In (I), the survey covered factory workers (kojo rodosha) in manufacturing establishments employing 50 or more regular production workers (joyo shokko).

3) In (III), the survey covered regular employees in manufacturing establishments with 5 or more regular employees. Regular employees were defined as the employees (a) whose contractual durations were longer than one month or (b) who were employed for a period shorter than one month but had been employed during previous two months for 18 days or more in each month. 
Figure 2. Industrial Production and Manufacturing Employment Indices in the U.S. and Japan, 1927-1940 (1929=100)

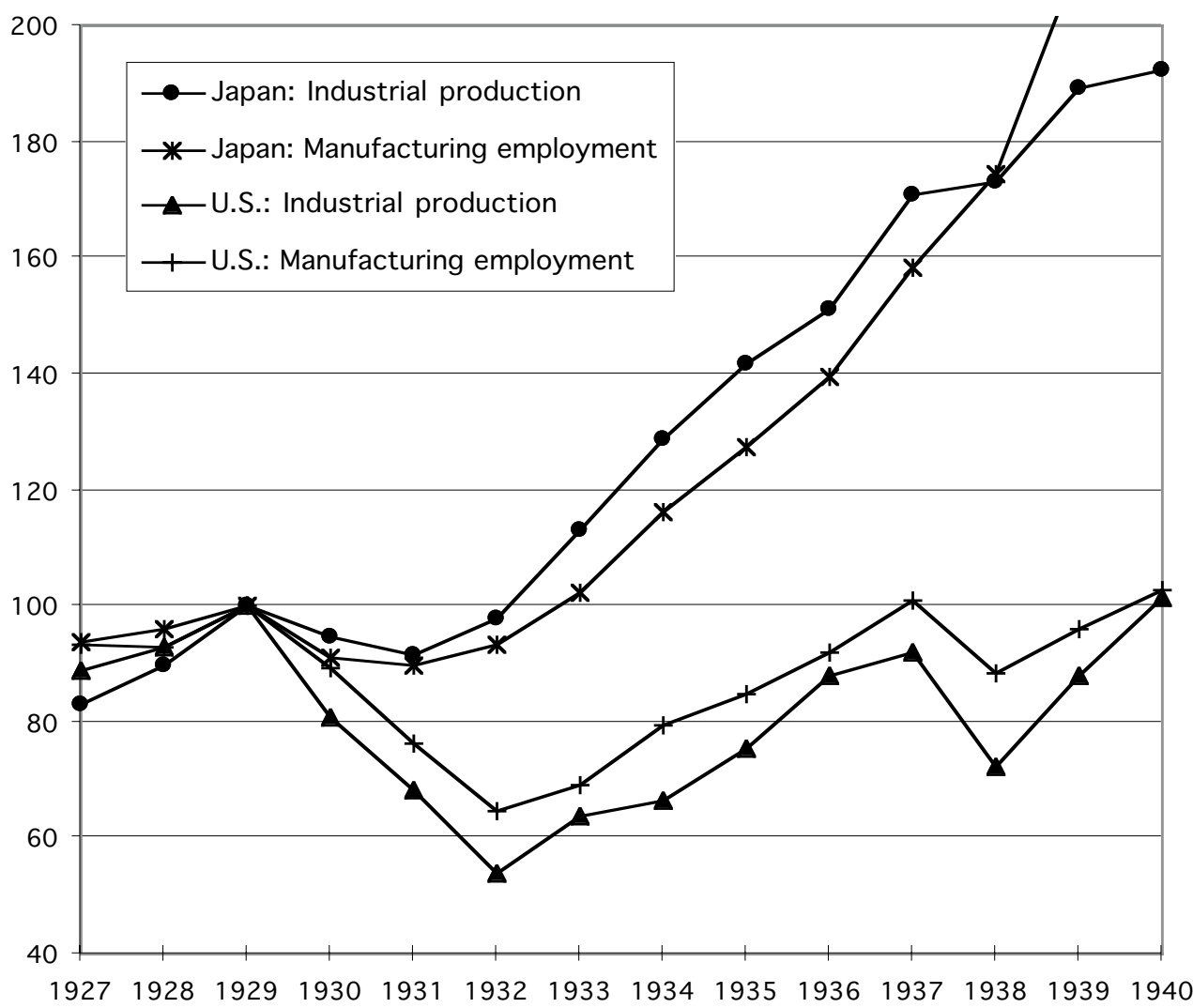

Source: U.S. Department of Commerce (1975), Historical Statistics of the United States, Series D130. Bank of Japan (1966), Hundred-Year Statistics of the Japanese Economy, p.397.

Showa Dojinkai (1973), Wagakuni Chingin Kozo no Shiteki Kosatsu (Historical Reflections on the Japanese Wage Structure), Statistical Appendix. 
Table 1. Corporate Personnel Programs in the U.S., 1928

\begin{tabular}{|c|c|c|c|}
\hline Personnel Programs & $\begin{array}{l}\text { Small Plants } \\
\text { (4,409 plants) }\end{array}$ & $\begin{array}{l}\text { Large Plants } \\
\text { (1,676 plants) }\end{array}$ & $\begin{array}{c}\text { Total } \\
(6,085 \text { plants })\end{array}$ \\
\hline \multicolumn{4}{|l|}{ A. Incentive Contracts } \\
\hline Retirement Pension Plan & $121(4.8 \%)$ & $474(28 \%)$ & 685 \\
\hline Group Life Insurance Plan & $1,600(36 \%)$ & $774(47 \%)$ & 2,374 \\
\hline Stock Ownership Plan & $163(3.7 \%)$ & $287(17 \%)$ & 450 \\
\hline Profit Sharing Plan & $168(3.8 \%)$ & $80(4.8 \%)$ & 248 \\
\hline Saving Plan & $168(3.8 \%)$ & $328(20 \%)$ & 496 \\
\hline Housing Plan & $264(6.0 \%)$ & $386(23 \%)$ & 650 \\
\hline Length-of-Service Bonus & $384(8.7 \%)$ & $183(11 \%)$ & 567 \\
\hline Paid Vacation Plan & $926(21 \%)$ & $427(25 \%)$ & 1,353 \\
\hline Plant Medical Service & $1,556(35 \%)$ & $1,027(61 \%)$ & 2,583 \\
\hline \multicolumn{4}{|l|}{ B. Human Capital Investment } \\
\hline Apprenticeship Training & $683(16 \%)$ & $499(30 \%)$ & 1,182 \\
\hline Training Unskilled or Semi-skilled & $472(11 \%)$ & $330(20 \%)$ & 802 \\
\hline Foreman Training & $216(4.9 \%)$ & $322(19 \%)$ & 538 \\
\hline General Education & $35(0.8 \%)$ & $119(7.1 \%)$ & 154 \\
\hline Internal Promotion & $176(4.0 \%)$ & $401(24 \%)$ & 577 \\
\hline \multicolumn{4}{|l|}{ C. Internal Enforcement Mechanisms } \\
\hline Picnics or Outings & $666(15 \%)$ & $657(39 \%)$ & 1,323 \\
\hline Athletic Teams & $454(10 \%)$ & $717(43 \%)$ & 1,171 \\
\hline Employee Club & $106(2.4 \%)$ & $288(17 \%)$ & 394 \\
\hline Employee Magazine & $97(2.2 \%)$ & $303(18 \%)$ & 400 \\
\hline Centralized Employment & $273(6.2 \%)$ & $701(42 \%)$ & 974 \\
\hline Centralized Discharge & $194(4.4 \%)$ & $401(24 \%)$ & 595 \\
\hline Personnel Department & $110(2.5 \%)$ & $575(34 \%)$ & 685 \\
\hline Suggestion System & $212(4.8 \%)$ & $389(23 \%)$ & 601 \\
\hline Safety Committee & $1,270(29 \%)$ & $1,126(67 \%)$ & 2,396 \\
\hline Group Meetings & $300(6.8 \%)$ & $251(15 \%)$ & 551 \\
\hline Mutual Benefit Association & $198(4.5 \%)$ & $498(30 \%)$ & 696 \\
\hline Employee Representation Plan & $110(2.5 \%)$ & $146(8.7 \%)$ & 256 \\
\hline
\end{tabular}

Source: NICB (1929), Industrial Relations Programs in Small Plants, Chapter II.

1) The number of plants adopting each welfare program is shown. All the programs were for bluecollar workers and were not required by law.

2) The survey covered 4,409 "small plants" employing 250 workers or less and 1,676 "large plants" employing more than 250 workers.

3) Saving plans included saving \& loan funds, saving \& investment funds, building \& loan funds.

4) Housing plans included company housing programs and home ownership plans.

5) Plant medical service included plant dispensary, nurses, physicians, hospitals, and special clinics. 
Table 2. Employee Representation Plans and Trade Unions in the U.S., 1919-1947

\begin{tabular}{||r|r|r|r|r|r||}
\hline Year & \multicolumn{1}{|c|}{$\begin{array}{c}\text { Companies } \\
\text { with ERPs }\end{array}$} & $\begin{array}{c}\text { The number of } \\
\text { ERPs }\end{array}$ & $\begin{array}{c}\text { Employees } \\
\text { covered by ERPs }\end{array}$ & \multicolumn{1}{|c|}{$\begin{array}{l}\text { Trade union } \\
\text { membership }\end{array}$} & $\begin{array}{c}\% \text { of ERP } \\
\text { coverage to } \\
\text { union members }\end{array}$ \\
\hline 1919 & 145 & 196 & 403,765 & $4,125,200$ & $9.8 \%$ \\
\hline 1922 & 385 & 725 & 690,000 & $4,027,400$ & $17.1 \%$ \\
\hline 1924 & 421 & 814 & $1,240,704$ & $3,536,100$ & $35.1 \%$ \\
\hline 1926 & 432 & 913 & $1,369,078$ & $3,502,400$ & $39.1 \%$ \\
\hline 1928 & 399 & 869 & $1,547,766$ & $3,479,800$ & $44.5 \%$ \\
\hline 1932 & 313 & 767 & $1,263,194$ & $3,144,300$ & $40.2 \%$ \\
\hline 1934 & N.A. & $1,075 *$ & $1,769,921$ & $3,069,000$ & $57.7 \%$ \\
\hline 1935 & N.A. & $1,577 *$ & $2,597,600$ & $3,753,300$ & $69.2 \%$ \\
\hline 1941 & N.A. & 598 & 411,000 & $8,698,000$ & $4.7 \%$ \\
\hline 1947 & N.A. & 222 & 469,000 & $14,595,000$ & $3.2 \%$ \\
\hline
\end{tabular}

Source: NICB (1925), The Growth of Works Councils in the United Sates, p.10.

NICB (1933), Collective Bargaining Through Employee Representation, p.16.

NICB (1933) Individual and Collective Bargaining under the NIRA, p.16.

NICB (1934), Individual and Collective Bargaining in May, 1934, p.12.

NICB (1936), What Employers Are Doing for Employees, p.10.

Jacoby (2000), "A Road Not Taken: Independent Local Unions in the U.S. since 1935," p.82, in Nonunion Employee Representation, edited by Kaufman \& Taras.

Troy (1965), Trade Union Membership, 1897-1962, p.1.

1) A large company with multiple plants or establishments typically had more than one ERP.

2) The numbers with $*$ were estimated assuming that the average number of employees per ERP remained constant $(1,647)$ between 1932-35. 
Table 3. The Cost of Personnel Programs in the U.S.

Cost as \% of Total Annual Payroll

\begin{tabular}{|c|c|c|c|c|c|c|c|}
\hline Cost of Program & $\begin{array}{c}\text { AMA } \\
(1925)\end{array}$ & $\begin{array}{l}\text { NICB } \\
(1925)\end{array}$ & $\begin{array}{l}\text { NICB } \\
(1928)\end{array}$ & $\begin{array}{l}\text { NICB } \\
(1929)\end{array}$ & $\begin{array}{l}\text { NICB } \\
(1934)\end{array}$ & $\begin{array}{l}\text { Other } \\
\text { Studies }\end{array}$ & Average \\
\hline sample size & 90 & 1 & 200 & 400 & 70 & & \\
\hline Pension & 0.33 & N.A. & 0.50 & 0.80 & N.A. & $0.61^{\mathrm{a}}$ & 0.71 \\
\hline Group life Insurance & 0.60 & 0.75 & 0.73 & 0.80 & 1.30 & & 0.73 \\
\hline Disability benefit & N.A. & N.A. & 0.20 & 0.30 & 0.78 & $0.46^{b}$ & 0.34 \\
\hline Profit sharing & N.A. & N.A. & 2.70 & 4.40 & 4.30 & & 3.80 \\
\hline Supplemental bonuses & N.A. & N.A. & 1.80 & 2.90 & N.A. & & 2.35 \\
\hline Housing program & 1.00 & N.A. & N.A. & N.A. & N.A. & & 1.00 \\
\hline Paid vacations & N.A. & N.A. & 1.50 & 0.90 & N.A. & $1.50^{c}$ & 1.30 \\
\hline Medical services & 0.32 & N.A. & 0.43 & 0.30 & 0.34 & & 0.35 \\
\hline Dining services & 0.31 & N.A. & 0.55 & 0.60 & N.A. & & 0.49 \\
\hline Recreational services & 0.26 & N.A. & N.A. & N.A. & 0.22 & & 0.24 \\
\hline Training\& education & 0.15 & 0.17 & N.A. & N.A. & 0.10 & & 0.14 \\
\hline Employee magazine & 0.21 & 0.10 & N.A. & N.A. & 0.10 & & 0.14 \\
\hline Health \& safety & 0.13 & 0.50 & 0.43 & N.A. & N.A. & & 0.35 \\
\hline Employment procedure & 0.31 & N.A. & N.A. & N.A. & 0.34 & & 0.33 \\
\hline Total (all 14 plans) & & & & & & & $12.26 \%$ \\
\hline Total (12 basic plans) & & & & & & & $6.11 \%$ \\
\hline
\end{tabular}

Source: AMA (1925), Cost Finding for Personnel Activities.

NICB (1925), Employee Magazines in the United States.

NICB (1928) The Economic Status of the Wage Earners in New York and Other States.

NICB (1929), Industrial Relations Programs in Small Plants.

NICB (1934), Effect of the Depression on Industrial Relations Programs.

a. Epstein (1926), The Problem of Old Age Pension in Industry, with the sample size 100.

b. BLS (1928), Bulletin No. 458, with the sample size 80.

c. BLS (1927), Vacation with Pay for Industrial Workers, with the sample size 90.

Note:

1) The costs of the respective welfare programs are expressed as $\%$ of total annual factory payroll.

All numbers are estimated by the author; details are available upon request.

2) All the costs are employers' expenses net of employee contributions.

3) Supplemental bonuses included length-of-service bonus, attendance bonus, and quality of product bonus.

4) The second last row reports total cost of all the 14 plans in the table.

5) The last row reports total cost of 12 "basic plans" excluding profit sharing plans and supplemental bonus plans. 
Table 4. Corporate Personnel Programs in Japan, 1921 and 1932

\begin{tabular}{|c|c|c|}
\hline \multirow[b]{2}{*}{ Corporate Welfare Programs } & \multicolumn{2}{|c|}{ Establishments with Programs } \\
\hline & $\begin{array}{c}\text { In } 1921 \\
\text { (157 large plants) }\end{array}$ & $\begin{array}{c}\text { In } 1932 \\
(2,310 \text { plants })\end{array}$ \\
\hline \multicolumn{3}{|l|}{ A. Incentive Contracts } \\
\hline Retirement Allowance or Pension & $73(47 \%)$ & $967(42 \%)$ \\
\hline Group Insurance Plan & $36(23 \%)$ & N.A. \\
\hline Non-work Injury \& Sickness Benefits & $107(68 \%)$ & $515(22 \%)$ \\
\hline Injury, Sickness \& Death Benefits for Family & $79(50 \%)$ & $227(9.8 \%)$ \\
\hline Stock Ownership Plan & N.A. & $63(2.7 \%)$ \\
\hline Profit Sharing Plan & & $272(12 \%)$ \\
\hline End-of-term Bonus & $126(80 \%)$ & N.A. \\
\hline Length-of-Service Bonus & $55(35 \%)$ & $102(4.4 \%)$ \\
\hline Savings Plan & $84(54 \%)$ & N.A. \\
\hline Loans to Employees & $33(21 \%)$ & $276(12 \%)$ \\
\hline Company Housing & $101(64 \%)$ & $796(35 \%)$ \\
\hline Housing Allowance & $20(13 \%)$ & $134(5.8 \%)$ \\
\hline Discount Purchase & $91(58 \%)$ & $777(34 \%)$ \\
\hline Plant Medical Care & $149(95 \%)$ & $1,109(48 \%)$ \\
\hline \multicolumn{3}{|l|}{ B. Human Capital Investment } \\
\hline Supplementary Education & $34(22 \%)$ & $480(21 \%)$ \\
\hline Corporate Training Program & $28(18 \%)$ & $249(11 \%)$ \\
\hline Company Library & $48(31 \%)$ & $811(35 \%)$ \\
\hline \multicolumn{3}{|l|}{ C. Internal Enforcement Mechanisms } \\
\hline Picnics or Field Days & $97(62 \%)$ & $863(37 \%)$ \\
\hline Social Gatherings & $90(57 \%)$ & $1,187 \quad(51 \%)$ \\
\hline Athletic Facilities & $60(38 \%)$ & $1,529(66 \%)$ \\
\hline Employee Magazine & $48(31 \%)$ & $287(12 \%)$ \\
\hline Employee Associations & $68(43 \%)$ & $919(40 \%)$ \\
\hline Suggestion System & $14(8.9 \%)$ & N.A. \\
\hline Safety Committee & N.A. & $1,385(60 \%)$ \\
\hline Mutual Aid Association & N.A. & $271(12 \%)$ \\
\hline Joint Administration & N.A. & $211(9.1 \%)$ \\
\hline
\end{tabular}

Source: Kyochokai (1924), Hompo Sangyo Fukuri Shisetsu Gaiyo (An Overview of Industrial Welfare Facilities in Japan); Shakaikyoku (1933, 1934), Kojo Kozan no Fukuri Shisetsu Chosa (A Survey on Welfare Facilities in Industrial Establishments), I-III.

1) The 1921 sample consists of 157 large private establishments employing 300 or more employees; the 1932 sample consists of 2,310 private establishments employing 100 or more employees.

2) All the programs were for blue-collar workers and were not required by law.

3) "End-of-term bonuses (kimatsu shoyo)" were bonuses given monthly or semiannual; some of them were profit sharing plans.

4) "Employee associations" include ERP, mutual aid associations (kyosai kumiai), employee clubs, and other employee organizations.

5) "Joint administration" includes employee participation in welfare administration through ERP, mutual aid associations, or other employee organizations. 
Table 5. Retirement Allowance Plans in Large Establishments in Japan, 1932

\begin{tabular}{||l|r|r|r||}
\hline \multirow{2}{*}{ Length of Service } & \multicolumn{3}{|c|}{$\begin{array}{c}\text { Amount of Allowance Stipulated } \\
\text { (days of wages) }\end{array}$} \\
\cline { 2 - 4 } & $\begin{array}{c}\text { A. Retirement due to } \\
\text { personal reasons }\end{array}$ & $\begin{array}{c}\text { B. Retirement due to } \\
\text { business reasons }\end{array}$ & $\begin{array}{c}\text { Average of } \\
\text { B-A A }\end{array}$ \\
\hline Less than 1 year & $0-10$ & $0-14$ & 2.0 \\
\hline $1-3$ & $7-35$ & $14-38$ & 5.0 \\
\hline $3-5$ & $37-61$ & $44-72$ & 9.0 \\
\hline $5-7$ & $63-88$ & $81-115$ & 22.5 \\
\hline $7-10$ & $97-162$ & $128-192$ & 30.5 \\
\hline $10-15$ & $147-286$ & $193-346$ & 53.0 \\
\hline $15-20$ & $281-446$ & $358-520$ & 75.5 \\
\hline $20-25$ & $415-575$ & $528-700$ & 119.0 \\
\hline \hline
\end{tabular}

Source: Zensanren (1932a), Wagakuni ni okeru Romusha Taishokuteate Seido no Genjo (The Conditions of Retirement Allowance Plans in Japan), pp.22-3; Zensanren (1932b), Wagakuni ni okeru Kaikoteate Seido no Genjo (The Conditions of Dismissal Allowance Plans in Japan), pp.22-3.

1) Using the same sample of 165 large establishments (employing 200 or more workers), the two surveys reported 145 retirement allowance plans and 142 augmented retirement allowance plans for production workers, respectively.

2) The ranges of the amount of allowances stipulated in the representative plans are shown.

3) The numbers in B are net of advanced-notice allowance (14 days of wages) mandated by the 1926 Revised Factory Law.

Table 6. Actual Payments of Retirement Allowance in Japan, 1929-33

\begin{tabular}{||c|c|r|r|r|r|r||}
\hline Year & $\begin{array}{c}\text { A. Number of } \\
\text { dismissals } \\
\text { due to business } \\
\text { reasons }\end{array}$ & $\begin{array}{c}\text { B. Number of } \\
\text { workers } \\
\text { receiving } \\
\text { allowances }\end{array}$ & B/A & $\begin{array}{c}\text { C. Average } \\
\text { allowance per } \\
\text { worker (yen) }\end{array}$ & $\begin{array}{c}\text { D. Daily } \\
\text { wage } \\
\text { (yen) }\end{array}$ & $\begin{array}{c}\text { C/D } \\
\text { (days of } \\
\text { wages) }\end{array}$ \\
\hline 1929 & 45,123 & 32,536 & $72.1 \%$ & 66.2 & 1.59 & 41.6 \\
\hline 1930 & 59,873 & 42,974 & $71.8 \%$ & 176.2 & 1.55 & 113.6 \\
\hline 1931 & 58,496 & 35,348 & $60.4 \%$ & 268.7 & 1.47 & 182.8 \\
\hline 1932 & 39,073 & 19,742 & $50.5 \%$ & 172.0 & 1.43 & 120.7 \\
\hline 1933 & 29,396 & 13,297 & $45.2 \%$ & 97.6 & 1.39 & 70.3 \\
\hline
\end{tabular}

Source: Shakaikyoku, Kojo Rodosha Kaiko Teate Chosa (Factory Workers Dismissal Allowance Survey), 1929-1933.

1) The survey covered 5,000 to 5,600 private factories employing 50 or more regular workers.

2) The reported allowances in $\mathrm{C}$ include the advanced-notice allowance (14 days of wages) mandated by the Revised Factory Law in 1926.

3) The wages were the average basic daily wages (teigaku chingin) of male blue-collar workers in private factories employing 50 or more regular workers reported in NRUS (1959). 